NIST Technical Note 2153

\title{
Ignitibility of Structural Wood Products Exposed to Embers During Wildland Fires: A Review of Literature
}

Shonali Nazare

Isaac Leventon

Rick Davis 
NIST Technical Note 2153

\section{Ignitibility of Structural Wood Products Exposed to Embers During Wildland Fires: A Review of Literature}

Shonali Nazare

Isaac Leventon

Rick Davis

Fire Research Division Engineering Laboratory

This publication is available free of charge from:

https://doi.org/10.6028/NIST.TN.2153

April 2021

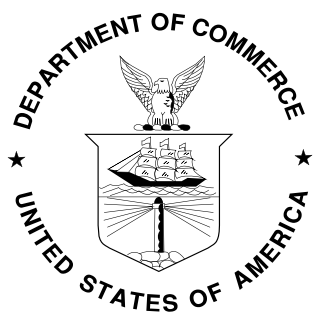

U.S. Department of Commerce

Gina M. Raimondo, Secretary

National Institute of Standards and Technology James K. Olthoff, Performing the Non-Exclusive Functions and Duties of the Under Secretary of Commerce for Standards and Technology \& Director, National Institute of Standards and Technology 
Certain commercial entities, equipment, or materials may be identified in this document in order to describe an experimental procedure or concept adequately. Such identification is not intended to imply recommendation or endorsement by the National Institute of Standards and Technology, nor is it intended to imply that the entities, materials, or equipment are necessarily the best available for the purpose.

National Institute of Standards and Technology Technical Note 2153 Natl. Inst. Stand. Technol. Tech. Note 2153, 55 pages (April 2021) CODEN: NTNOEF

This publication is available free of charge from: https://doi.org/10.6028/NIST.TN.2153 


\begin{abstract}
The ignitability of structural components due to ember attack is a common cause of the structural fires in wildland-urban interface (WUI) communities. To fire-harden structures in WUI communities, it is important to be able to quantitatively predict the ignitability of wooden substrates in response to ember exposure. To commence this effort, in this manuscript, past studies have been compiled and analyzed to identify the knowledge gaps. Key topics are reviewed, including ignition of structures in WUI fires, measurement of thermal response of solid wood products used in residential structures, controlling mechanisms of ignition and sustained smoldering of wood, measurement of ember properties, real-scale and bench-scale experiments assessing ember ignitability of structural components, and surrogate ignition sources for assessing smoldering propensity of the wooden substrates. Existing standard test methods have also been reviewed in the light of their ability to represent common exposures observed in the WUI environment.
\end{abstract}

The experimental data from past studies have provided guidance in developing building codes and standards for reducing the susceptibility of structures to WUI fires. Relationships have been developed between ember size, fuel moisture content, and ignition frequency of common structural components. However, most of these data are qualitative, and the studies largely report on ignition probabilities of the fuels studied under specific test conditions. Advanced experiments have been designed to quantify the thermal characteristics of embers (i.e., ember temperature and heat transfer as well as factors and conditions that affect each one) thus providing information on net heat flux, peak heat flux, and heat flux and temperature distributions of ember piles. These studies also assess wind conditions and heating times required for initiation of smoldering and subsequent transitioning to flaming combustion, and provide an initial understanding of selected factors affecting ember ignitability of wood-based materials. Despite these efforts, available empirical data on the ember ignition of solid wood substrates are limited and is not sufficient to predict the ignitability and sustained smoldering of wood products exposed to an arbitrary set of conditions they may face in the WUI. Without the ability to quantitatively predict the ember ignitability of wooden substrates outside of specific, pre-defined experimental conditions, it is difficult to develop a system for risk assessment and tools to reduce structural losses from wildland fires.

A comprehensive review of alternative ignition sources as surrogates for an ember or pile of embers has indicated that electrical resistance heaters are capable of initiating smoldering ignition in solid wooden substrates. The power output of such heaters can be carefully controlled to generate well-defined heat transfer conditions comparable to those measured for piles of real embers, which may develop in WUI fires. It is anticipated that the use of surrogate ignition sources will provide a robust, accurate, and efficient approach to validate the performance of computational models designed to quantitatively predict the smoldering behavior of a combustible solid based on simulation of the chemical and physical mechanisms controlling this behavior and knowledge of the material's thermophysical properties.

\title{
Key words
}

Ember ignition; smoldering; structure ignitions; surrogate ignition source; wildland urbaninterface fires. 


\section{Table of Contents}

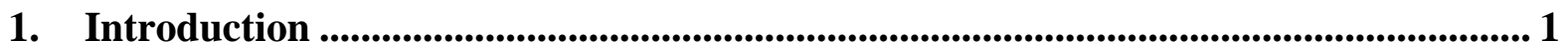

2. Ignition of Structures in WUI Fires....................................................................... 3

3. Physical and Thermal Characteristics of Embers ............................................................ 5

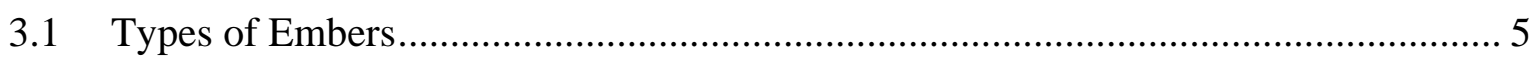

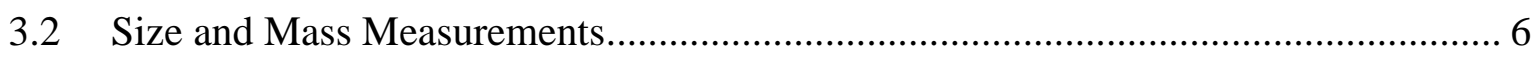

3.3 Temperature Measurements of Embers .......................................................... 8

3.4 Thermal Energy Measurements......................................................................... 10

4. Smoldering Ignition of Solid Wood....................................................................................... 12

4.1 Controlling Mechanisms of Smoldering or Glowing Combustion....................... 12

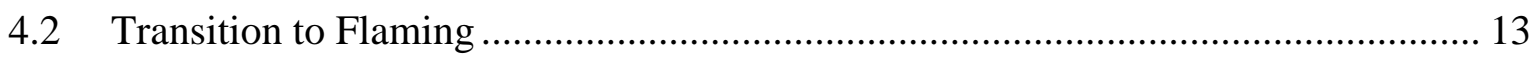

4.3 Effect of Airflow ......................................................................................... 14

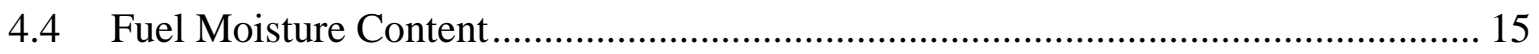

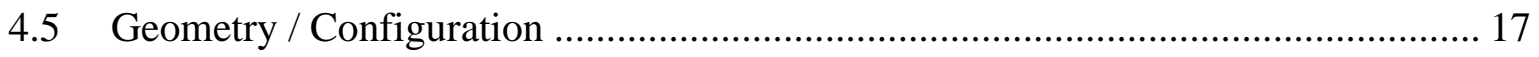

4.6 Experimental Investigation of Smoldering in Response to Radiative Heating ......... 18

4.7 Experimental Investigation of Smoldering in Response to Direct Contact Heating. 19

4.8 Criteria for Smoldering Ignition in Wood .......................................................... 19

5. Experimental Studies of Ember Ignition of Structural Components ......................... 21

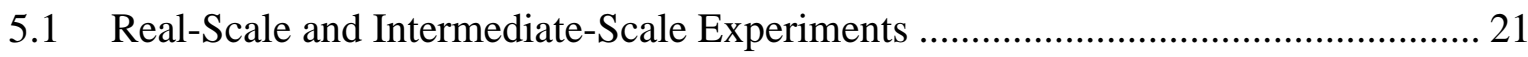

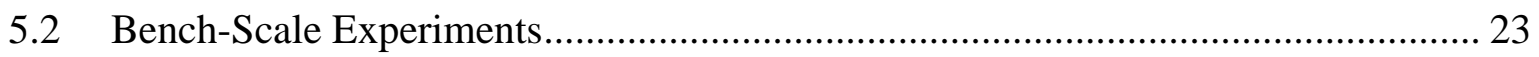

6 Existing Test Methods for Assessing Ignitability of Structural Components in WUI Settings and their Limitations........................................................................................................... 25

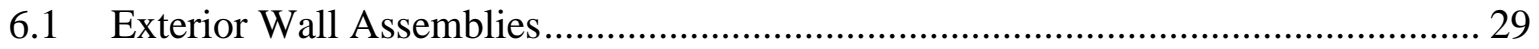

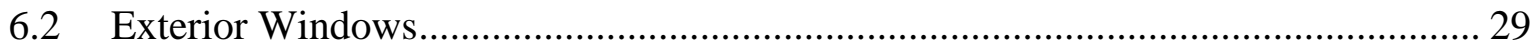

6.3 Eaves and Horizontal Projections...................................................................... 30

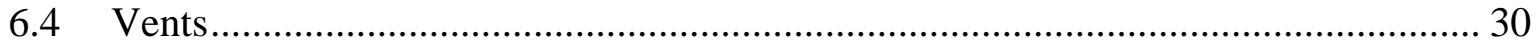

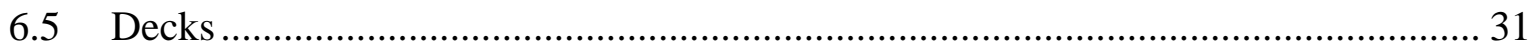

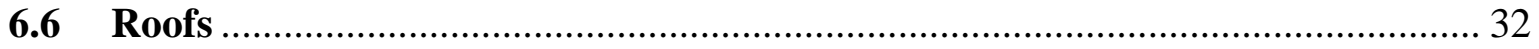

7 Potential Candidates for Surrogate Ignition Sources ................................................. 33

8 Summary and Future Work ............................................................................................... 36

References........................................................................................................................................ 39 


\section{List of Tables}

Table 1. Standard test methods for assessing ignitability of structural components in WUI communities. 


\section{Introduction}

Spot fires or spotting fires have been reported as one of the major causes of loss of residential structures in wildland-urban interface (WUI) areas [1-6]. These are defined as secondary fires that occur when embers or firebrands attack structures ahead of the leading edge of a wildland fire. These secondary spotting fires may start off as outdoor structural ignitions after breaching the structure envelope by firebrands or as small interior fires that have the potential to grow until flashover occurs and destroys the whole structure. Embers and firebrands are practically similar objects that act as ignition sources in WUI fires, and the terms are often used interchangeably. However, according to Babrauskas [7], embers refer to small hot particles, whereas firebrands have characteristic aerodynamic properties (shape and mass) that keep them airborne over large distances. For the purpose of this review, all hot, glowing particles are addressed as embers.

Generally, spotting fires occur on porous vegetative fuel; however, structure ignitions from embers are also very common. Structural fires tend to generate additional embers that have the potential to ignite nearby structures or cause additional vegetative spotting fires. Roof-toroof fire spreads by embers are more common in structural fires within WUI communities as opposed to structures getting engulfed by flames from the exterior. This is partly attributed to ease of ignition of common roofing materials, the extensive surface area exposed to an ember shower, and capability of subsequent ember production from burning roofs [8]. Vulnerabilities of buildings to wildfire exposures have been recognized and reported by Manzello et al. [9]. It is difficult to control wildfires directly; however, it is certainly feasible to reduce structural fires by fire hardening the structures located in the WUI communities.

Several methods for mitigating structural losses have been implemented by providing homeowner education on the suitable treatment of fuel in the structure ignition zones and adoption of building codes and standards [10], including design modifications [11]. These methods are largely based on best practices guidelines when applied to vegetative fuels (e.g., thinning fuels within a certain distance from the structure) [12]. Building codes and standards for structural components and design considerations have been developed based on engineering judgment and knowledge gained by qualitative evaluations of structural performance in past WUI fires. Section 6 of this report describes widely used standard test methods for structural components, including those found in Chapter 7A of the California Building Code. Many of these standards evaluate flaming and radiant heat exposures [13]; however, non-flaming smoldering embers may land on the combustible substrate and accumulate for a long time. A pile of smoldering embers, under optimal conditions (e.g., pile size and mass, incident heat flux, and environmental conditions), can act as an ignition source for the underlying and/or adjacent fuel. This kind of exposure - where a combustible solid substrate is in direct contact with a smoldering ignition source - is not included in the existing test methods (except for roofing and decking materials). This is notable because burned structures within the WUI communities have been lost long after they might be considered safe from direct flaming exposures $[3,6,8,9,14-16]$. Accumulation of embers in a corner or crevice configurations is very likely, and the probability of ignitions in such configurations is very high $[11,17]$. The need to develop measurement science tools to assess ignition propensity of structural components when exposed to a pile of smoldering embers recently gained momentum following focused workshops on Structure Ignition in Wildland-Urban Interface (WUI) Fires $[13,18,19]$ and is under experimental research and development. 
Several studies on the ignition probabilities of structural components using embers produced under controlled laboratory conditions are reported in the literature [20-26]; however, none of these studies have quantified the ignition strength of the embers. In the very early studies, Waterman and Takata [20] reported on the ignitability of a range of structural materials in an urban residential setting. Embers used in their study were fabricated in the laboratory and were typical of those produced by common roofing materials. The ignitibility of various fuels by embers was studied under typical wildland fire conditions. More recently, Manzello's pioneering work on the development of experimental apparatus to generate embers led to a full-scale and reduced-scale facility with a unique capability of generating continuously fed wind-driven embers with size and mass similar to those generated in actual WUI fires [27]. The wind speed was varied to study its effects on the ignitibility of the substrate fuel. Experimental data from these studies have provided guidance in developing building codes and standards for reducing the susceptibility of structures to WUI fires [28]. Relationships have been developed between ember size, fuel moisture content, and ignition frequency of common structural components. However, most of these data are qualitative, and the studies largely report on ignition probabilities of the fuel studied. Very recently, the research groups at the University of Edinburgh [23], University of Maryland [29-32], University of California Berkeley [33], and others [34] performed advanced experiments to study thermal characteristics of embers (e.g., ember temperature and heat transfer as well as factors and conditions that affect each one) and identify conditions under which the wooden substrate would ignite. These experiments provide insights into measurement techniques and associated uncertainties. These studies also facilitated quantification of thermal properties of ember piles including net heat flux, peak heat flux, heating times, and wind conditions required for initiation of smoldering and subsequent transitioning to flaming combustion. In general, these studies provided an initial understanding of selected factors affecting ember ignitability of wood-based materials.

Ember ignitability of wooden substrates is a complex problem as it requires knowledge of thermal characteristics of embers and also the material properties of the substrate fuel that control its thermal, physical, and chemical response to heating, in addition to environmental conditions. Extensive literature [35-50] is available on pyrolysis and combustion of wood exposed to radiant heating; however, systematic theoretical studies on wood ignition by embers and its subsequent burning are inadequate. Limited empirical data available on the ember ignition of the solid wood substrate are not sufficient to predict ignitability and sustained smoldering. Without the ability to quantitatively predict the ember ignitability of wooden substrates, it is difficult to develop a system for risk assessment and tools to reduce structural losses from wildland fires. In order to commence with this effort, it is important to integrate past studies and identify knowledge gaps. The goal of this literature review is thus to compile and analyze previous research findings on:

- $\quad$ ignition of structures in WUI fires,

- measurement of thermal response of solid wood products used in residential structures,

- controlling mechanisms in the ignition and sustained smoldering of wood,

- measurement of ember properties,

- $\quad$ real-scale and bench-scale experiments, and 
- $\quad$ surrogate ignition sources for assessing the smoldering propensity of the wooden substrate.

The knowledge gained from this review will be helpful in developing a surrogate ignition source, standard test methods, and effective approaches for limiting the ignition of wood-based structural components in general.

\section{Ignition of Structures in WUI Fires}

In early 1990, during the study of the Oakland Hills fire in California and its impact on wooden structures, Sketchler et al. [51] identified three sources of structural ignition and fire spread within WUI residential communities: direct flame impingement, ember exposure, and thermal radiation from flames. However, over the past three decades, WUI researchers have noted that ember exposure or combined exposure scenarios (i.e., embers and other exposures) are always reported as a significant cause of ignition and/or fire spread in WUI communities [7, 9, 52-57]. In this section, various structural ignition and fire spread mechanisms in WUI communities are reviewed.

As a wildfire approaches the perimeter of WUI communities, flame contact with and flame radiation to structures, especially roofs, occurs largely due to the burning of vegetative fuel (potentially by high-intensity crown fires). Wind-driven flames from burning of ornamental residential vegetation at a distance of $1.5 \mathrm{~m}(5 \mathrm{ft})$ from the primary structure may ignite flammable components of the structure and cause some damage to the exterior. However, it has been reported that such ignitions are very unlikely to cause total destruction of a structure until an opening is formed and flames and/or embers penetrate into the interior [52]. Intermittent flaming exposure from vegetative fires at a distance of $3 \mathrm{~m} \mathrm{(10} \mathrm{ft)} \mathrm{to} 3.6 \mathrm{~m}(12 \mathrm{ft})$ is not capable of producing sufficient heat to ignite the wooden exterior of a structure [53,58]. However, it is very likely that the intense flaming exposure from a burning structure at a distance of $3 \mathrm{~m} \mathrm{(10} \mathrm{ft)} \mathrm{can} \mathrm{set} \mathrm{the} \mathrm{neighboring} \mathrm{structure} \mathrm{on} \mathrm{fire.} \mathrm{Such} \mathrm{structure-to-structure}$ fires are very common in WUI areas since in many cases, the structural fuel load is larger than the fuel load of adjacent ornamental vegetation surrounding a structure or wildland fuel load [59]. Cohen [53] has also shown that high-intensity fires from structures can spread to tree canopies and subsequently to the adjacent structures.

Maranghides and Mell [54] characterized structural ignitions in three categories using visual evidence (from homeowners and first responders including police and firefighters), digital images before and after the WUI fires, and a timeline of the events. Category A (uninterrupted vegetative fire or ember ignitions) was defined as potential structure ignition due to the uninterrupted spread of fire through vegetation to the structure. By definition, all the structures at the perimeter of the WUI community belong to this category. Category B (vegetative fire or ember ignition) was defined as structure ignitions due to the burning of vegetative fuel in the periphery of the structure. The authors assumed that the ignition of peripheral vegetative fuel might have occurred by ember exposures since the fire front had not approached yet. Category C (ember ignitions) was defined as structure ignitions solely by ember exposure, primarily due to ember intrusion into the structure and igniting the combustibles within the structure. This type of exposure can be identified by the presence of unburned vegetation surrounding the structure and absence of direct wildfire exposure. 
The majority of structural fires in WUI communities are known to generally start from small ignitions caused by ember penetration inside the structures, and if these small fires are not extinguished in time, they could grow until flashover occurs to bring the whole structure down [60]. Recent reviews [7, 9, 55, 56] on exposure conditions and structure ignitions in WUI communities confirm that indoor ignitions usually occur due to embers entering through openings such as eaves or attic vents and igniting highly flammable soft furnishing products. Babrauskas [7] highlighted a study in Australia that reported $70 \%$ of structures destroyed in WUI fires were caused by ember ignition. Maranghides and McNamara [61] reported that embers generated from the burning of adjacent combustibles such as fences, decks, landscape timbers, mulch beds, attached outdoor stairs, and piles of firewood were generally responsible for igniting the interior of residential structures. They identified secondary structures such as sheds and garages to be a major source of ember generation, exposing primary structures to increased hazardous conditions. As more structures are ignited, ember flux increases in the WUI area [59], thus furthering fire spread. As mentioned earlier, a large number of houses are also known to be have their roofs ignited due to ember exposure. The likelihood of roof ignition by embers is much higher for wooden shingle roofs. Larger exposed surfaces and buildup of vegetative fuel are generally associated with the fire spread on roofs [8].

The modes of ignition and fire spread within WUI residential communities include radiant heating of structures from the spreading wildland fire and/or from other nearby burning houses. While flaming embers generated by an intensely burning structure are capable of igniting structures that are $1000 \mathrm{~m}$ away [59], intense radiant heat from a burning structure can easily

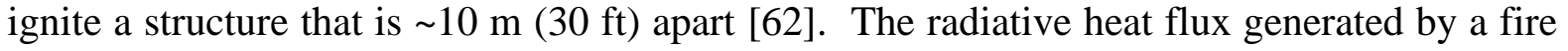
decreases with the square of the distance away from the flame front [6]. Thus, structure separation distance is extremely crucial in controlling structure-to-structure fire spread. Generally, such fire spread occurs by breaking windows, thereby exposing interior combustible materials to an intense heating source. The breaking of windows may occur due to high winds, thermal damage of window panes or deformation of window frames. Vinyl window frames, for example, can melt and deform due to radiant heat exposure from an adjacent fully-involved structure fire, thereby releasing the windowpane and forming an opening. A vinyl soffit can melt when exposed to low incident heat flux of around $8 \mathrm{~kW} / \mathrm{m}^{2}$, and breakage of a single thickness unhardened glass window can occur from $8 \mathrm{~kW} / \mathrm{m}^{2}$ to $20 \mathrm{~kW} / \mathrm{m}^{2}$ [6] and form an opening to expose the interior of the structure to embers or direct flames. Although it is evident from the surveys of several WUI fires that the majority of structural fires are ignited within the structures by embers [56], these studies demonstrate that radiant heat exposures can be sufficiently high to ignite some exterior combustibles [6, 62], to initiate smoldering combustion, or to act in a complementary manner to facilitate ignition by embers. Due to the rapid developing nature of WUI fires and their sensitivity to several contributing factors (e.g., topography and weather), it is very difficult to isolate the cause of structure ignitions.

In addition to describing structural fire spread mechanisms, several post-fire investigations of structural fires in WUI communities within the US [2, 10, 51, 53, 59-63] and Australia [64-66] have concluded that the chance of a house surviving the passage of a wildland fire was determined by defensible space, the distance between structures, non-combustible roofing and siding, type of roof constructions, types of soffit, presence of deck/balcony, exterior cladding, percent wood exterior, and environmental conditions [63]. Laranjeria and Cruz [56] have recently shown that residential structures in WUI areas of Mediterranean countries are less vulnerable to ignition and fire spread due to non-combustible construction materials used in 
the building envelope. Wood and wood products are commonly used in US residential buildings, but wood is highly prone to smoldering when exposed to heat and fire, particularly in wildfire exposures. It is therefore important to understand the vulnerabilities of structural components in US homes, particularly, to ember exposures.

\section{Physical and Thermal Characteristics of Embers}

For an ember to be a potential ignition source to start a new fire, it must have conditions suitable for self-sustained smoldering or flaming, including a critical mass of fuel and sufficient oxygen supply. Upon landing of the ember, some of the heat generated by the smoldering or flaming combustion is transferred to the substrate. The amount of heat transferred and hence the spotting potential strongly depends on the characteristics (porous/solid) and configuration (crevice/corner/gaps, with or without fine fuel such as litter or vegetative debris) of the substrate [67].

In this section, shape, size, mass, burning behavior, thermal characteristics, and spotting potential of embers (or a pile of embers) are reviewed. In the literature, several studies have characterized embers or firebrands in terms of physical and thermal properties. Physical properties include dimensions, mass, and types of embers. In this context/review, thermal characteristics include ember temperature, mass loss rate, burning rate, heat flux from the burning ember, and amount of heat transferred to the substrate. The shape and size are important physical properties that govern burning [22,32] as well as transport [68] of embers while the ignition probabilities or spotting potential of embers depend upon their thermal properties.

\subsection{Types of Embers}

Embers can be produced from burning of vegetative fuels including the bark of trees, twigs, needles, leaves, and pinecones [69]. Embers can also be produced from burning structural wooden components such as wood shingles, sheathing materials including plywood and OSB, framing lumber including door frames and window sills, and wooden fences [8, 20, 24, 70, 71]. Manzello et al. [24] have shown that different species of wood generate different sizes and shapes of embers. For example, burning of a redwood fence produced larger embers compared to a Western redcedar fence. Waterman and Tankata study [20] concluded that wood-shingled roofs had the highest potential to produce embers amongst the variety of materials (wood shingles, plywood, dimensional sheathing, and framing lumber) tested. Significantly large amounts of embers from structural components are generated following a structural collapse. Embers produced from structural components are typically larger and have higher densities compared to embers produced from wildland fuel, making them effective ignition sources for starting spotting fires [20].

Embers landing on fuel beds may be found in two possible states; flaming or glowing. It has been reported that when embers land on fuel beds, they are most likely in a glowing state and not flaming [8, 72]. However, these glowing embers have the potential to reignite and transition to flaming. Studies [22, 73-75] have shown that the flaming embers almost always result in ignition of a porous vegetative fuel bed, whereas glowing embers may or may not lead 
to ignition. Ganteaume et al. [73] investigated the flammability of fuel beds and the propensity of embers to ignite vegetative fuel beds commonly found in southern Europe. Testing of embers suggested that the capability of embers to ignite porous vegetative fuel beds was higher when embers landed in the flaming mode in the absence of wind than when glowing embers landed in the presence of wind.

In a separate study, Ganteaume et al. [68] performed an extensive characterization of embers in their laboratories. They studied flammability characteristics of embers including ignitability, combustibility, and sustainability. Coupled together, these three flammability properties of the embers were reported to quantify ember efficiency in ignition of spot fires. Ignitability was assessed by the time to ignition or frequency of ignition of forest fuel fragments while sustainability was quantified as the duration of flaming in the embers. The combustibility of embers produced from vegetative fuel was assessed by measuring the gross heat of combustion. Depending on their physical and flammability characteristics, embers were classified into three different types. Heavy embers (e.g., pinecones) could sustain flames for longer duration and could be the most efficient embers in spotting fires. Light embers with high surface-to-volume ratio had a lower ability to sustain flames. These embers were consumed very quickly and were less efficient in causing spotting fires. Light embers with low surface- to-volume ratio sustained flaming and were efficient for short-distance spotting fires. Moghtaderi et al. [76] studied extinction and re-ignitability of embers in wildfires and reported that thermally thick embers were less susceptible to extinction and more prone to reignition.

Matvienko et al. [77] proposed a 3-D mathematical model of vegetative porous fuel bed ignition by glowing embers during wildland fires. They measured ignition times for single pine bark and pine twig embers and found that the pine bark was not able to ignite the pine litter. The mathematical model suggested that a single pine bark ember less than $5 \mathrm{~cm}$ long and less than $800{ }^{\circ} \mathrm{C}$ was not capable of igniting the fuel bed. However, pine twigs were able to ignite pine litter. To investigate this phenomenon, Warey [72] studied the influence of thermal contact between a glowing ember and the target fuel on the resultant heat transfer into the fuel bed. Two types of ember shapes were studied, a disk-shaped ember similar to tree bark and a cylindrical ember resembling a twig. The study concluded that higher temperatures were observed in the fuel bed for the cylindrical embers in spite of poor contact, compared to the disk-shaped ember. This was attributed to a higher magnitude of the radiation heat flux from the cylindrical ember compared to conduction heat transfer from the disc shaped ember. The findings are in agreement with those of Tao et al. [32] and Matvienko et al. [77] discussed above.

\subsection{Size and Mass Measurements}

Ember size (i.e., mass and shape) controls its duration of burning and its aerodynamics during travel while its size and mass at landing determine the possible energy transfer to the substrate $[8,23,78]$. Distance traveled by an ember is affected by the type of vegetation, moisture content, intensity of the fire, and wind speed [79]. Wind has competing effects on the mass of the embers. Higher wind speeds can generate larger embers but can also result in a higher burning rate, thereby consuming more mass during transport [78]. Higher wind speeds could also extinguish the embers. Laboratory characterization of embers, which often limits wind speed and the dimensions of the test chamber, has shown weak inverse correlations between 
mass and traveling distance as well as projected area and traveling distance. With respect to full forest-scale studies on wildfires, the researchers found it difficult to characterize ember production and transport given the many uncertainties associated with the process of placing collectors and analyzing the sources of the embers [79].

Manzello and Suzuki have reported extensively on ember production from real-scale building components [80-82]. They measured the size and mass of embers generated from building components made from wood-based materials under different wind speeds. Woycheese [83] reported that disc shaped embers were more likely to be produced from structural components as compared to spherical, cylindrical, and cone-shaped embers produced from vegetative fuels. In Ref [81] Suzuki and Manzello have provided a review of studies on the quantification of embers from building components and real WUI fires. Important findings from their review and experimental work are listed below:

1. Very small embers with projected areas of less than $25 \mathrm{~mm}^{2}$ dominated the size distribution.

2. Mass distribution of an individual ember varied from $0.1 \mathrm{~g}$ to $1 \mathrm{~g}$.

3. The projected area and mass of embers decreased with increasing lofting distance.

4. The projected area of the embers was linearly proportional to the mass of the ember [82].

5. Embers had larger projected area and higher mass as the wind speed increased.

6. The type of materials used in the construction of houses had a significant impact on the size and mass of embers generated [80].

In most studies, the size of embers was determined by measuring holes in the polyurethane sheets on which the embers were collected or by catching embers in aluminum pans with or without water. More recently, Hedayati et al. [78] developed an automated image processing algorithm to measure the projected area of the embers collected in water pans. Based on projected area, travelling distance, and wind speed the authors predicted the mass of embers. Bouvet et al. [84], for the very first time, have developed a tool to characterize time-resolved fluxes and size distribution of airborne embers during WUI fires. The newly developed threedimensional (3D) measurement diagnostic tool uses two imaging techniques: 3D Particle Tracking Velocimetry (3D-PTV), allowing for time-resolved mapping of firebrand trajectories and 3D Particle Shape Reconstruction (3D-PSR) to build 3D models of individual firebrands based on the Visual Hull concept.

In their experiments, Fateev et al. [85] concluded that the increase in particle size led to a decreased mass loss rate and increased smoldering time. This was in agreement with the findings of Waterman and Takata [20] who reported that the larger brands with an area greater than $645 \mathrm{~mm}^{2}\left(1 \mathrm{in}^{2}\right)$ formed from sheathing lumber constituted the most hazardous embers compared to those generated from cedar shingles. They attributed this to the fact that lumber had five times higher density than cedar shingles and that higher density lumber had inherent ability to self-reinforced glowing combustion.

While size and mass measurement of an individual ember provided significant insight into what range of sizes should be produced by an ember generator for the ignitibility of porous fuels, the size of individual embers is not the key factor of interest when studying ignitability of structures by ember exposures after the embers land. As mentioned earlier, embers tend to 
accumulate on solid substrates, particularly into gaps or re-entrant corner spaces. Hakes et al. [29] and Salehizadeh [31] reported a drastic increase in heating from a pile of embers as compared to heating from individual embers; the effect of individual ember diameter was reported to be negligible while studying thermal characteristics of the pile of embers [29, 32].

Manzello and Suzuki [28] reported on ember pile mass necessary to produce ignition of decking materials. In their limited number of experiments, they recorded a range of pile mass (85 $\mathrm{g}$ to $283 \mathrm{~g}$ ) necessary for ignition of various wood species. They claimed that the accumulation of embers in larger piles resulted in self-sustaining smoldering and subsequent transitioning to flaming ignition of decking materials. Further studies [86] showed that the mass of embers required for flaming ignitions under a wind speed of $8 \mathrm{~m} / \mathrm{s}$ was considerably less compared with the mass required under a wind speed of $6 \mathrm{~m} / \mathrm{s}$. The authors attributed this phenomenon to higher surface temperatures of the accumulated embers at higher wind speed. Since the onset of smoldering ignition was somewhat ambiguous, no correlation between time to ignition and mass of ember piles was reported.

In a more recent study, Santamaria et al. [23] reported flaming ignition of solid wood substrate by $24 \mathrm{~g}$ of piled embers. Sixteen grams of smoldering embers was not able to initiate flaming ignition in flat wooden substrate under a no-wind condition. The ember pile mass was estimated by assuming approximately $60 \%$ mass reduction of embers after burning. They claimed that ember accumulation of $98 \mathrm{~g} / \mathrm{m}^{2}$ in actual field experiments corresponded very well with the critical ember mass determined for ignition of a wooden substrate in small-scale experiments. It was assumed that total possible mass collected in a critical location was not needed to be scaled for the small-scale experiments since it was expected that all the embers falling in relatively large areas would accumulate in a small area considered in their smallscale experiments.

The above studies indicate that although physical characteristics of individual embers (e.g., size, shape, and mass) influence ember transport and spotting fires in porous vegetative fuels (e.g., pine needle beds), individual embers do not typically ignite combustible solids and these physical properties are not the key characteristics of interest when studying ember piles. Thus, when assessing the ignition of structural components (e.g., solid wooden substrates), properties of ember piles such as total mass, bulk density, pile height, and geometry of the deposited pile - in addition to wind speed [23, 29, 31, 32, 34] - play more decisive roles in influencing the thermal behavior (i.e., temperature and heat transfer) of smoldering embers and thus the response of the combustible solids upon which they land.

\subsection{Temperature Measurements of Embers}

Fateev et al. [85] defined the minimum temperature of a smoldering ember as the minimum temperature that maintained its thermal decomposition. During this period the ember continued to lose mass however, heat transfer to the underlying substrate might be negligible. In thermograviametric (TGA) tests on pine bark samples (conducted in $94 \%$ of air at a heating rate of $10 \mathrm{~K} / \mathrm{min}$ ), Fateev et al. measured a minimum smoldering temperature of $190{ }^{\circ} \mathrm{C}$. Thermal analysis data suggested that the oxidation of resinous components occur at around $190{ }^{\circ} \mathrm{C}$. In a separate experiment, they measured temperatures of a smoldering ember using 3 infrared cameras. High temperatures in the range of $700{ }^{\circ} \mathrm{C}$ to $800{ }^{\circ} \mathrm{C}$ were recorded during 
initial smoldering of the ember with a gradual decrease in temperature following thermal decomposition of the ember. They reported excessive fluctuation of temperatures (up to $200{ }^{\circ} \mathrm{C}$ ) due to the release of pyrolysis products and subsequent combustion thereof, followed by the formation and ablation of ash.

Preliminary studies [21, 85] on temperature measurement of glowing embers used infrared cameras and thermocouples. Manzello et al. [21] measured the top surface temperature from the center of glowing embers by simultaneously using an infrared camera and a thermocouple. They adjusted the emissivity of the IR camera until the temperature measurements converged with those recorded by the thermocouple. The average top surface temperatures of the embers were measured over 15 min period under different wind conditions. For an airflow of $1.3 \mathrm{~m} / \mathrm{s}$, the average temperature of embers varied from $525{ }^{\circ} \mathrm{C}$ to $600{ }^{\circ} \mathrm{C}$ and for airflow of $2.4 \mathrm{~m} / \mathrm{s}$, the average temperature varied from $650{ }^{\circ} \mathrm{C}$ to $700{ }^{\circ} \mathrm{C}$.

Addressing the limitations of infrared thermography associated with its dependency on surface emissivity, Urban et al. [33] recently used color pyrometry to measure temperature of an ember placed in a wind tunnel. They compared color pyrometry with infrared thermography measurements taken simultaneously and concluded that the color pyrometry was more accurate and appropriate for ember temperature measurements than infrared thermography. Using color pyrometry, they reported mean temperature in the range of $750{ }^{\circ} \mathrm{C}$ (at $1 \mathrm{~m} / \mathrm{s}$ wind speed) to $950{ }^{\circ} \mathrm{C}$ (at $4 \mathrm{~m} / \mathrm{s}$ wind speed) and maximum ember temperature (at ignition and before burnout) up to $1100{ }^{\circ} \mathrm{C}$. Kim and Sunderland [30] reported similar temperatures using a similar technique.

Hakes et al. [29] and Salehizadeh [31] measured temperatures in a pile of embers using type $\mathrm{K}$ thermocouples and thin skin calorimeters. They recorded higher temperatures with larger piles and at the center of the pile. Higher temperatures at the center were attributed to reradiation within the ember pile. Measured peak temperatures of $400{ }^{\circ} \mathrm{C}$ and $700{ }^{\circ} \mathrm{C}$ were reported for ember piles of $4 \mathrm{~g}$ and $16 \mathrm{~g}$, respectively. Lower temperatures of smaller piles compared to larger piles were attributed to poor contact and coverage between the sensors and the embers. Larger piles also resulted in prolonged heating times. Tao et al. [32] measured temperatures of the ember pile in three regions including upstream, center, and downstream regions of the pile/substrate interface. They reported that the peak temperatures were recorded at the center of the pile and that the downstream temperatures were always higher than in the upstream region.

It is evident from the above studies that the temperature of an ember or pile of embers is a transient property that varies spatially. The temperature of an ember is strongly affected by the wind speed such that the surface temperature increases with increasing wind speed. Temperature data can provide insight into thermal properties of embers, but caution should be used with these measurements as ember temperature is highly non-uniform spatially, and significant uncertainties can arise due to poor thermal contact (thermocouples) or unknown/varying emissivities (infrared thermography). Moreover, thermocouples could act as unintended heat sinks, thereby lowering the local temperature and interrupting the ignition process. 


\subsection{Thermal Energy Measurements}

The temperature measurements discussed above can be used to qualitatively infer how much heat is being released by an ember. However, it is the heat transfer from the ember to the combustible substrate it lands on that determines the ignition propensity of the substrate. Following the pioneering work by Manzello et al. [21] and researchers [29, 31, 32] at the University of Maryland, recent studies [34, 87] have reported on high resolution heat flux measurements from smoldering embers.

For a cylindrical ember exposed to an airflow of $1.3 \mathrm{~m} / \mathrm{s}$, Manzello et al. [21] estimated heat flux of $23.4 \mathrm{~kW} / \mathrm{m}^{2}$. The calculated heat flux for an ember exposed to higher airflow increased to $34.2 \mathrm{~kW} / \mathrm{m}^{2}$ for an airflow of $2.4 \mathrm{~m} / \mathrm{s}$. Ember heat fluxes have been measured by Hakes et al. [29] using thin skin calorimeters and water-cooled heat flux gauges. They measured heat fluxes from laboratory-fabricated smoldering embers and examined the effects of ember diameter $(6.35 \mathrm{~mm}$ to $12.75 \mathrm{~mm})$, deposited pile mass $(2.7 \mathrm{~g}$ to $9.6 \mathrm{~g})$, and wind $(1.8 \mathrm{~m} / \mathrm{s})$. For individual embers, high heat fluxes were measured over longer duration for embers with larger diameters when compared to embers with smaller diameters. This was attributed to larger contact area of larger embers with the sensor. However, for ember piles, the heat flux dependence was not as crucial as heat transfer via re-radiation. Experiments with larger piles revealed that the larger piles generated higher peak heat fluxes at the center of the pile, highlighting the role of re-radiation within the pile of embers. Moreover, the sensors remained more completely surrounded by embers thus preventing convective cooling by the wind. Average heat fluxes were reported in the range of $15 \mathrm{~kW} / \mathrm{m}^{2}$ to $25 \mathrm{~kW} / \mathrm{m}^{2}$ with peak heat flux values ranging approximately between $20 \mathrm{~kW} / \mathrm{m}^{2}$ and $60 \mathrm{~kW} / \mathrm{m}^{2}$. They concluded that the pile mass was the most important variable affecting the net heat flux imparted on to the substrate. They reported the largest pile mass of $9.6 \mathrm{~g}$ for the longest semi-steady period of heat flux.

Salehizadeh [31] extended the work of Hakes et al. [29] and measured heat fluxes from ember piles with deposited masses of $4 \mathrm{~g}, 8 \mathrm{~g}$, and $16 \mathrm{~g}$ having bulk densities of $38.3 \mathrm{~kg} / \mathrm{m}^{2}, 46.8$ $\mathrm{kg} / \mathrm{m}^{2}$, and $54 \mathrm{~kg} / \mathrm{m}^{2}$ respectively. An increase in ember pile mass from $4 \mathrm{~g}$ to $8 \mathrm{~g}$, deposited on same area of approximately $100 \mathrm{~mm} \times 100 \mathrm{~mm}$, showed an increase in peak heat flux; however, a further increase in pile mass of $16 \mathrm{~g}$ did not show a linear increase in the peak heat flux values. An average heat flux fluctuated between $10 \mathrm{~kW} / \mathrm{m}^{2}$ and $15 \mathrm{~kW} / \mathrm{m}^{2}$ for a pile mass of $16 \mathrm{~g}$ exposed to $0.5 \mathrm{~m} / \mathrm{s}$ wind speed. An increase in duration of heating was, however, reported for increasing pile sizes and lower wind speeds. The average and the peak heat flux values measured by Salehizadeh were very similar to those reported by Hakes. His experiments suggested that higher heat fluxes were produced at the center of the pile. Higher heat fluxes seen by the substrates were attributed to re-radiation amongst the embers in the pile.

Using the same technique as Hakes et al. [27] and Salehizadeh [29], Tao et al. [32] measured heat fluxes from piles of artificially made embers (wooden pins, discs, and dowels) and embers made from naturally occurring fuels (eucalyptus sticks and pine bark flakes). Keeping the mass of the deposited pile constant at $4 \mathrm{~g}$, they measured different bulk densities of the piles which were attributed to the type of embers and the way they assembled in the pile. Ember piles made from eucalyptus sticks and pine bark flakes had lower bulk densities and higher 
peak heat fluxes compared to ember piles composed of pins and discs. The average heat fluxes varied between $5 \mathrm{~kW} / \mathrm{m}^{2}$ and $25 \mathrm{~kW} / \mathrm{m}^{2}$ depending on the type of embers.

Lattimer et al. [34] used an inverse heat transfer method using IR thermography of a stainless steel plate to quantify high resolution heat flux distributions from an individual ember on a horizontal surface. In addition to the effects of wind and ember shape on the heat flux, they quantified the effects of ember orientation with respect to wind direction and ember contact with the surface on the heat flux distribution. Embers fabricated from oak wood were varied in geometries that resulted in different surface contact areas with the substrate. The wood pieces were allowed to burn for $40 \mathrm{~s}$ and lost about $40 \%$ to $50 \%$ of their initial mass before being placed on the substrate. Heat fluxes from individual embers were measured under a nowind condition, with wind direction parallel to the long axis of the ember, and wind direction perpendicular to the long axis of the ember. In the absence of wind, peak heat flux values in the range of $30 \mathrm{~kW} / \mathrm{m}^{2}$ to $90 \mathrm{~kW} / \mathrm{m}^{2}$ were recorded. Embers with maximum contact with the substrate resulted in higher heat flux while embers with added notches at the bottom resulted in lower peak heat flux and rapid decay in heat flux. The addition of wind resulted in higher peak heat fluxes $\left(55 \mathrm{~kW} / \mathrm{m}^{2}\right.$ to $\left.85 \mathrm{~kW} / \mathrm{m}^{2}\right)$ that remained at an elevated level for a longer period of time, and a characteristic double peak was reported in the temporal profile of the heat flux. The airflow around the embers with notches generated higher heat fluxes compared to embers with direct contact with the plate. This observation was attributed to additional surfaces exposed to wind experiencing further oxidation. The study also looked at spatial distribution of heat flux in an ember exposed to wind. It was shown that higher heat fluxes were generated at the leading edge of an ember where the wind initially encountered the ember.

Since the heat flux from the embers can vary over a wide range, their ability to ignite the substrate very much depends on minimum smoldering time and their thermal energy. The minimum smoldering time of an ember is the time over which it retains its ignition potential. As noted from the above discussion, the heat flux from an ember is not always steady and increases in the presence of wind. Salehizadeh [29] estimated critical heat flux for smoldering ignition from critical smoldering temperatures but concluded that the critical heat flux parameter only provided a point value to describe an ignition condition and was unable to account for cumulative heating effect leading up to ignition. 


\section{Smoldering Ignition of Solid Wood}

In this section, the onset of smoldering in a solid wood slab using different modes of heating is reviewed. Since the transition from smoldering to flaming ignition is a major cause of concern in WUI fires, the studies investigating mechanisms causing the transition have also been reviewed. Also reviewed in this section are the effects of airflow, moisture content, and sample configuration on the smoldering behavior of solid wood substrate.

\subsection{Controlling Mechanisms of Smoldering or Glowing Combustion}

Smoldering combustion is a relatively slow, low temperature, flameless, exothermic reaction. Smoldering is particularly hazardous because it allows for the ignition of fuels and provides a "pathway to flaming" that can be initiated under conditions that could not directly cause flaming ignition (e.g., by weaker ignition sources) [88, 89]. Multiple thorough review papers describe the key physical and chemical mechanisms controlling smoldering behavior [90, 91]; a brief summary of the key processes is presented here.

In smoldering combustion, oxidation occurs at the surface of the condensed phase fuel. Thus, sustained smoldering requires a porous combustible solid (or permeable aggregate) that allows for oxygen transport through the fuel bed and provides a large surface area to volume ratio, which promotes oxidation of the fuel directly at its surface. This process is exothermic, and when the heat generation within the sample exceeds heat losses to the surrounding, the combustion is characterized to be self-sustained. From this point forward, smoldering can propagate without any external heat input. In many wood species, self-heating has been found to occur at about $160{ }^{\circ} \mathrm{C}$ [92]. Smoldering reaction rate depends on local heat transfer and oxygen availability, both of which are strongly influenced by the rate of convection to the reaction zone. Consequently, the permeability of the medium can have competing effects: greater permeability can increase oxygen availability, which will increase reaction rate, but sufficiently high airflow can increase cooling, thus decreasing reaction rate. Other key factors that strongly influence smoldering behavior and rate include: fuel moisture content (endothermic, heat sink); fuel size and configuration (internal heating and heat storage propensity; buoyancy induced convection); and ambient conditions such as airflow (oxygen availability), relative humidity, temperature, and external heating exposures (all of which can impact local heating and reaction rate at the smoldering front).

There have been several recent computational modeling studies that provide detailed multiphysics representations of the chemical and physical mechanisms controlling smoldering behavior [93-96]. Much is known about the fundamental mechanisms controlling smoldering combustion and propagation, and correspondingly these models demonstrate qualitative agreement with observed spatial distributions of species and temperature around the smoldering front, charring patterns, and the dependence of smoldering propagation on oxygen availability. However, open questions remain regarding the ability of state-of-the-art computational models to quantitatively predict behaviors such as ignition time, smoldering propagation rate, and transition to flaming under a range of configurations and heating

scenarios. Further study is also needed to develop a robust, accurate, and efficient approach to determine and validate the relevant model input parameters (e.g., material thermophysical 
properties) controlling smoldering behavior and to ensure that they're broadly applicable. Notably - an accurate determination of the kinetics and energetics of oxidative decomposition, especially with explicit considerations for sample surface area and oxygen availability, will strongly impact the fidelity of such simulations.

In the light of the above controlling mechanisms, wood presents as an ideal fuel for the occurrence of self-sustained smoldering. Furthermore, the poor thermal conductivity of wood limits heat dissipation away from the point of smoldering initiation, thereby supporting sustained smoldering. Moreover, wood char invariably cracks as it is formed [97]. Air permeates through the cracks, and the reaction can be self-sustaining in the presence of a sufficient amount of fuel, enough oxygen, and limited heat losses. Thus, the cracks in wood have a noticeable influence on the propagation of the smoldering process. Similarly, the presence of gaps between the structural components was noted to have a significant influence on sustained smoldering [98]. In the context of WUI fires, self-sustained smoldering can be characterized as the ignition of the substrate by embers to the point where the substrate continues to smolder well after embers have ceased smoldering.

\subsection{Transition to Flaming}

The transition from smoldering to flaming is one of the important mechanisms of fire spread in WUI fires [8]. Such flame spread mechanism where glowing embers initiate smoldering which quickly transitions to flaming combustion is commonly seen in mulch beds. The flames from the burning of mulch have been found to eventually ignite wall sidings [99] and fences [24]. The other example where the transition from smoldering to flaming combustion is frequently seen is with wooden decks. Decks present a unique challenge in WUI fires and are known to be a major cause of structural losses [17]. Manzello et al. [28] have shown that glowing embers accumulate within the gaps of the deck boards which can result in selfsustaining smoldering of the boards that eventually transition to flaming ignition.

Santoso et al. [14] define the transition from smoldering to flaming combustion as a quick initiation of homogeneous gas-phase ignition following smoldering combustion. During smoldering combustion, the fuel undergoes rapid oxidation followed by a sharp temperature rise. The oxygen supply to the reaction zone is important at this stage. If the amount of volatile products released during smoldering is sufficient to form a combustible mixture and the temperature of combustible mixture is sufficiently high, then the flaming ignition of the gas phase occurs and smoldering combustion transitions to flaming combustion [77]. Hagen [100] showed that to get the transition to a flaming fire, smoldering and secondary char oxidation must coexist. Secondary char oxidation is defined as oxidation of char produced during the initial smoldering of the solid fuel. This usually occurs in presence of excess oxygen and results in higher temperatures due to high heats of combustion of the char. They also suggested that the time to the onset of secondary char oxidation is important for the transition to occur. For the transition to occur, secondary char oxidation must occur while uncombusted solid fuel is still producing sufficient pyrolysis gases. Flaming combustion does not occur if the secondary char oxidation occurred after the sample was consumed completely by the smoldering front and production of gaseous fuel had ceased [101]. Essentially, the transition needs both (a) production of gaseous pyrolyzates in sufficient rates/quantities/local 
concentrations for ignition in the gas phase and (b) an ignition source, hence the need for glowing in the solid phase where those pyrolyzates are released.

The role of embers in transitioning from smoldering to flaming process is not well understood but is apparently affected by ember size and composition, wind velocity, and the moisture content, spatial arrangement, and continuity of the fuel bed [102, 103]. The velocity of smoldering and the peak temperature are the key parameters for smoldering to transition to flaming combustion. Salehizadeh [31] studied the probability of transition to flaming in smoldering ember piles and reported that a higher wind speed was required for smaller pile mass to transition to flaming as compared to a lower wind speed for larger pile mass. Despite similar contact area with the wooden substrate, smaller pile mass needed more oxygen for more heat production to cause the transition from smoldering to flaming combustion compared to larger pile mass.

\subsection{Effect of Airflow}

Most studies on ember generation, transport, and ignition of the substrate have examined the effects of wind velocity. These studies $[8,78,79]$ have shown that wind is the most critical factor in determining the ember hazard during the wildfires and that it plays an important role in the ignition of fuel substrate. Within the scope of this review, only the effects of wind on the ignition of fuel substrate are reviewed.

Several studies have reported on effects of wind speed on smoldering ignition of substrate fuels including porous fuels [104, 105], and solid wooden substrates [14, 21, 29, 31, 32, 97, 98]. It is generally concluded that airflow has two competing effects on the smoldering combustion of fuel substrate. The increased supply of oxygen can enhance char oxidation and pyrolysis reaction rates resulting in greater heating and greater production of pyrolyzates to facilitate early flaming ignition. Alternatively, the surface temperatures can remain low by convective cooling, and the airflow can dilute flammable gas mixtures thereby delaying flaming ignition. However, Salehizadeh [31] indicated that the effect of increased rates of oxidation in solid fuel substrates is considerably larger than the cooling effects under a wind speed range from 0.5 $\mathrm{m} / \mathrm{s}$ to $2.5 \mathrm{~m} / \mathrm{s}$.

In the presence of airflow, a larger amount of oxygen supply to the surface of the heated fuel substrate promotes char oxidation reactions generating sufficient heat to overcome heat losses to the surroundings and accelerate the rate of pyrolysis until a flammable fuel-air mixture is formed [105]. Manzello et al. [21] have shown that no ignitions of solid wood products exposed to smoldering embers occurred at a lower wind speed of $1.3 \mathrm{~m} / \mathrm{s}$; however, ignitions were noted at the wind speed of $2.4 \mathrm{~m} / \mathrm{s}$. On the contrary, Torero et al. [106] suggested that the forced convective flow under higher wind speed generally dilutes flammable gases, resulting in longer times to flaming ignition. They also pointed out that once ignition occurred, more complete combustion of the fuel occurred due to improved mixing conditions with higher wind speed. The likelihood of smoldering combustion transitioning to flaming was also noted in the presence of high wind speeds. In their experimental studies, Salehizadeh [31] and Kasymov [107] noted that smoldering rate increased with wind speed and became more repeatable at higher wind speeds, while lower wind speeds exhibited more stochastic behavior, i.e., flaming ignition behavior was found to be more variable and the probability of flaming combustion was low, especially for high-density fuel substrates. 
Bilbao et al. [38] studied the effects of wind speeds on smoldering and flaming ignition of pinewood exposed to different radiant heat fluxes. In general, when comparing the results for different wind speeds, larger differences in times to flaming ignitions were observed than in times to smoldering. This was explained on the basis that flaming ignition, as a gas-phase process, is affected more than smoldering by convection. As has been mentioned earlier, the wind speed can affect the heat losses, oxygen concentration at the surface of the sample, and indirectly, the smoldering temperature. The effect of wind speed on flaming ignition is much more direct, affecting the temperature and the concentration of the combustible gaseous mixture.

Salehizadeh [31] reported a considerable effect of wind speed on heating duration, peak heat flux, and peak temperature of ember piles. Under high wind speeds, an increase in the rate of oxidation resulting in higher temperatures and heat fluxes in glowing embers was noted. The effect of wind speed on peak heat flux is anticipated as higher wind speeds produce higher temperatures as a result of increased surface oxidation. Increased oxidation will invariably increase heat fluxes to the surface. As heat is released at a higher rate, embers burn out faster, resulting in a reduced duration of heating. At lower wind speed, the oxidation rate of the embers is relatively small, allowing ash layer growth to insulate the embers. Under these conditions, minimal degradation of the fuel substrate was observed in porous cellulosic insulation [105].

Rein et al. [93] have shown that the direction of airflow with respect to the direction of smolder propagation has a significant influence on the heating process in polyurethane foam. They noted that in backward smoldering where the air flows in the direction opposite to that of smolder propagation, airflow carries the heat away from the smoldering zone to the ash layer, thereby reducing the amount of heat supplied for heating the fuel. In forward smoldering where the oxidizer flows in the same direction as the smolder propagation, the airflow transfers heat from the smoldering zone to the unreacted fuel, resulting in a more efficient fuel heating process.

\subsection{Fuel Moisture Content}

It is well-established that the thermophysical properties of wood or any cellulosic fuel strongly depend on its moisture content and that the moisture generally retards the process of pyrolysis and ignition of wood. A review of recent WUI fire investigations by Maranghides et al. [6, 54, $61,63]$ have indicated that the largest structural losses in WUI fires are associated with prolonged drought, high local temperatures $\left(30^{\circ} \mathrm{C}\right.$ to $\left.45^{\circ} \mathrm{C}\right)$, low relative humidity $(5 \%$ to 10 $\%)$, and very high winds ( $8 \mathrm{~m} / \mathrm{s}$ to $25 \mathrm{~m} / \mathrm{s})$. Generally, researchers have tested three typical conditions for ember ignition of fuel: 1) testing at normal laboratory condition, 2) oven-dry samples, and 3) samples with $50 \%$ moisture. The oven-dry samples provide the worst-case scenario while the normal laboratory conditions of $20{ }^{\circ} \mathrm{C}$ and relative humidity of $40 \%$ to 60 $\%$ reflects the normal seasonal moisture retention properties of the wood product tested [108]. On a typical wildfire day, atmospheric conditions of $40^{\circ} \mathrm{C}$ and $10 \%$ relative humidity have been noted, and the moisture content of wood exposed to such atmospheric conditions for more than 10 days is reported to be $5 \%$ [109]. Similarly, multiple studies have shown that such atmospheric conditions can similarly reduce moisture contents in local vegetation and increase the severity of the fire hazard $[8,15,56,74]$. 
The moisture content in the substrate fuel is as important as the moisture content of the fuel from which embers are generated. The moisture content in the fuel from which the ember is generated affects the time to ignition, thermal degradation, combustion and flaming duration, and hence the heat transfer of an ember to the substrate [68]. Likewise, the moisture content in the substrate fuel affects its ignitability and subsequent flame spread during wildfires. Several researchers $[46,49,68,110-112]$ suggested a linear relationship between time to ignition and fuel moisture content, mainly by experimental means and simple regression analysis.

The majority of studies [67, 73-75, 102, 104, 111-117] reporting largely on the effects of moisture content on ember ignitability of substrates focus on porous vegetative fuels including pine needles, mulch, leaves, and grass. While the ignitability of porous vegetative fuel is not the focus of this review, some findings from these studies can provide useful insights on the effects of moisture content on the ignitability of solid wood substrates.

In their field experiments, Davies and Legg [113] have shown that certain shrubland vegetation with a moisture content of $70 \%$ and above failed to ignite with spot (drip-torch) and line ( 2 $\mathrm{m}$ long ) ignition sources while a moisture content of $60 \%$ or less tends to develop fires very rapidly. However, laboratory experiments by Grishin et al. [112] have reported that the critical value for moisture content for cedar needles ignited by individual embers is about $13 \%$. This difference in results could be due to the presence of wind which was not mentioned or discussed in either study or due to difference in fuel composition. The size of embers also has a significant impact on critical moisture content for the ignition of the fuel. Larger embers with high heat energy are capable of igniting vegetative fuel bed with a higher moisture content of about $40 \%$ [116]; however, the largest surrogate ember used in the study [109] was unable to ignite the solid wood with a moisture content of $17 \%$ or more. This disparity in ignitability of fuel substrates can be attributed to the ease of moisture evaporation. Moisture evaporation is much easier in case of porous fuel bed compared to solid wood substrate. Compared to porous vegetative fuel, higher heat energy is required to evaporate moisture from solid wood and thus less heat energy is available for pyrolysis and subsequent ignition [114]. Grishin et al. [58] reported that timber with a moisture content of about $37 \%$ was not ignited by radiant and convective heat fluxes, in the absence of embers. These studies clearly indicate that fuel moisture content determines a limiting condition for the ignition of fuel and that the critical moisture content depends on the type of fuel and the ignition source.

Recently, Bartlett et al. [114] extensively reviewed the role of moisture content on the burning behavior of solid wood under radiant heating conditions, and their findings are of more relevance to this review since heat transfer from embers is predominantly radiative. Under radiant heat fluxes, the ignition temperature is significantly affected by the moisture content [49]. Earlier studies [35, 41, 46, 49, 109, 110] have shown that the samples containing moisture have increased ignition temperature and reduced smoldering velocity. Kuznetsov and Filkov [46] quantified the effect of moisture content on the ignition of various wood species and reported that an increase in moisture content in wood by a factor of 10 resulted in increasing its ignition time by more than $50 \%$. In the presence of moisture, the smoldering propagation can decrease by a factor of two and transitioning to flaming combustion can be prevented. The reduction in the rate of smoldering is often attributed to the vaporization of moisture [118]. This process absorbs heat which, in a dry sample, would otherwise pyrolyze the fuel. Swann et al. [41] studied the effect of preheating on the smoldering ignition of maple plywood. They 
concluded that the preheating of the wood had little effect on the minimum heat flux for ignition and the ignition temperature; however, the time to ignition was markedly reduced by the prolonged preheating that essentially removed moisture from the plywood.

Collectively, these results indicate that, while a single 'critical moisture content' may not exist for all scenarios, ambient conditions in regions prone to wildfires can induce low moisture contents in local vegetation and wood products, and this reduced moisture content in combustible solids has been widely demonstrated to significantly increase the likelihood of ignition and rate of flame spread $[109,110]$. Thus, in the context of assessing the ember ignitability of structures or structural components, testing of oven-dry samples represents the worst-case scenario.

\subsection{Geometry / Configuration}

The onset and development of smoldering is greatly influenced by sample size, geometry, and configuration. The effect of sample orientation (horizontal and vertical) on the pyrolysis and ignition of wood exposed to radiant heat has been studied by several researchers $[35,36,43$ $45,119,120]$. These studies concluded that the heat transfer, the pyrolysis gas plume, and the ignition mechanism are affected by sample orientation. Generally, the critical heat flux and surface temperature for piloted ignition of wood in vertical orientation were reported higher than that required for horizontal orientation in the cone calorimeter experiment. This was attributed to the differences in radiation attenuation in horizontal and vertical sample orientations owing to the difference in the structure of the pyrolysis gas plume and the fact that radiation absorption by pyrolysis gas was significantly different in the two configurations. Yang et al. [120] reported that for horizontal samples, absorption of radiation by pyrolysis gas is stronger, and hence the net incident heat flux into the sample surface is less than for vertical samples. Thus, in the presence of a piloted ignition source, the ignition times of horizontal samples are slightly longer than the ones of vertical samples, despite the same distance between the sample and the radiant heater. In the vertical orientation, fuel gases flow away quickly upwards under the buoyant force, so the concentration of fuel gases near the sample surface is lower. However, the pyrolysis gases would mix with air and form a flammable mixture to ignite fairly quickly in the presence of the ignition source [119]. The autoignition ignition times for vertically oriented samples are, however, longer than those recorded for horizontally oriented samples [43]. This can be attributed to the fact that the thickness of the gas layer is thinner for vertically oriented samples due to stronger buoyant convection, and it takes longer time for the combustible mixture to reach the critical flammability limit for autoignition to occur.

In the case of ember exposures, embers generally tend to accumulate on solid substrates, particularly in gaps or re-entrant corner spaces. Re-entrant corner configurations, crevices, and gaps within structural components are most vulnerable to the accumulation of embers and subsequent smoldering from ember exposure [21, 23, 28, 98, 109]. Ignition potential of common building materials including plywood and oriented strand board (OSB) was investigated by placing multiple embers in the crevice configuration of wood-based materials [21]. Based on the results, Manzello et al. concluded that a critical angle between two wooden planks forming a crevice must be between $90^{\circ}$ and $135^{\circ}$ for ignition to occur. This critical angle facilitated sufficient heat transfer from the embers to the wooden substrate for the 
ignition of the latter to occur. It was indicated that re-radiation was a dominant mode of heat transfer in crevice or re-entrant corner configuration. The transition from smoldering to flaming is generally observed to occur in gaps or voids $[17,24,97,98,100,121]$. When lodged in the corner or gap, for example, gaps in decking planks, the heat losses from the embers are minimal. An increased flow of air into the reaction zone due to the gap, results in increased heat production, causing glowing and in some cases transition to flaming.

\subsection{Experimental Investigation of Smoldering in Response to Radiative Heating}

Several researchers $[38,39,41,42,44,45]$ have studied the smoldering behavior of various wood species under radiant heat flux ranging from $7 \mathrm{~kW} / \mathrm{m}^{2}$ to $60 \mathrm{~kW} / \mathrm{m}^{2}$ in the cone calorimeter. It is important to review these studies since it provides insight into the thermal conditions under which wooden substrates exhibits smoldering and/or flaming ignition.

Depending on the experimental conditions and duration of testing, different studies reported different critical heat flux values for glowing ignition in wood specimens. Bilbao et al. [38] studied the influence of convection on smoldering and flaming ignition of wood using different air flows over a sample. The main objective of this work was to predict the time at which the sample started to deteriorate. Smoldering time was defined as the time at which glowing of the sample occurred from the time of sample exposure. Tests were conducted for $900 \mathrm{~s}$, and smoldering was observed only at applied heat fluxes between $20 \mathrm{~kW} / \mathrm{m}^{2}$ and $40 \mathrm{~kW} / \mathrm{m}^{2}$. The authors reported that smoldering was not observed in the samples exposed to heat fluxes greater than $40 \mathrm{~kW} / \mathrm{m}^{2}$ since flaming ignition occurred almost spontaneously under such high heat fluxes. Heat flux of $40 \mathrm{~kW} / \mathrm{m}^{2}$ was therefore suggested as the maximum heat flux for smoldering to occur in wood sample. The surface temperature of the sample under $40 \mathrm{~kW} / \mathrm{m}^{2}$ was $525^{\circ} \mathrm{C}$ which was considered as the critical surface temperature for spontaneous ignition to occur. The critical heat flux of $20 \mathrm{~kW} / \mathrm{m}^{2}$ for smoldering was reported for a limited heating period of $900 \mathrm{~s}$. The critical surface temperature of $300{ }^{\circ} \mathrm{C}$ and time to smoldering ignition of $423 \mathrm{~s}$ were reported. Boonmee and Quintiere [42, 44] reported that glowing ignition temperature increased from $317^{\circ} \mathrm{C}$ to $400{ }^{\circ} \mathrm{C}$ as the incident heat flux increased from $10 \mathrm{~kW} / \mathrm{m}^{2}$ to $30 \mathrm{~kW} / \mathrm{m}^{2}$. Depending on the incident heat flux, surface temperatures from $200{ }^{\circ} \mathrm{C}$ to 400 ${ }^{\circ} \mathrm{C}$ were reported by other studies [35, 39, 42, 44, 45].

Gratkowski et al. [39] studied glowing ignition in maple wood exposed to heat fluxes closer to critical heat flux between $6 \mathrm{~kW} / \mathrm{m}^{2}$ and $15 \mathrm{~kW} / \mathrm{m}^{2}$. The minimum heat flux for smoldering ignition was experimentally determined to be $7.5 \mathrm{~kW} / \mathrm{m}^{2}$ with smoldering ignition time in excess of $2 \mathrm{~h}$. The surface temperature of the sample was recorded to be at $270{ }^{\circ} \mathrm{C}$. The authors also investigated the role of self-heating in smoldering ignition whereby slow exothermic oxidation reactions propagates within the fuel bed without any external heat input. Using detailed thermocouple measurements through the sample thickness, they showed that the depth at which glowing occurs was reduced with increasing incident heat flux.

Generally, researchers concluded that the process of smoldering was controlled by many physical and chemical mechanisms and that the surface temperature at ignition depended not only on the material properties but also strongly on the experimental conditions (irradiation and sample configuration). The ignition time was found to be directly proportional to the thermal inertia of wood, ignition temperature, and external heat flux. 


\subsection{Experimental Investigation of Smoldering in Response to Direct Contact Heating}

Significant number of studies [21, 23, 26, 28, 29, 31, 86, 97-99, 110, 122-124] have reported on smoldering of solid wood due to direct contact heating. A majority of the studies by Manzello et al. address the ignition probability of wooden components exposed to smoldering embers while limited studies have attempted to measure heat transfer from the embers or surrogate embers to the wooden substrate. Heat transfer from smoldering embers to a wooden substrate can occur by conduction, convection, or radiation. For conductive ignition, a hot object has to be in direct contact with the fuel. The geometry of the hot object has been shown to affect the ignition temperature for smoldering combustion [102]. The contact between the ember and the substrate is critical in determining the mode of heat transfer and probability of ignition. Heat transfer is most likely to occur via conduction if the contact between the embers and the substrate is fairly good. If the contact between embers and the substrate is not perfect, i.e., the heat flow is distorted, heat transfer is more likely to occur via radiation [31]. The conduction heat transfer from the ember to the substrate also depends on the porosity of the fuel and the temperature difference between the ember and the substrate. Yang et al. [42] have shown that ignoring the influence of pyrolysis and volatile transfer, thermal conduction is faster in low-density wood species. The inherent chemical composition of the different wood samples, however, has no influence upon thermal conduction [125]. Studies [72, 126] have also shown that heat conduction can initiate smoldering with the lowest heat flux. Nonetheless, radiation between the solid surfaces of the oxidizing char has been shown to be the dominant heat transfer mode [29, 31, 32, 97].

\subsection{Criteria for Smoldering Ignition in Wood}

The most widely used criterion for ignition in wood exposed to radiant heating is the critical ignition temperature, followed by the critical heat flux for ignition, and mass loss rate. For a thermally thick solid exposed to constant radiant heat flux, the critical temperature criterion calculates the time to ignition based on the assumption of a surface ignition temperature. The mass loss rate criterion assumes that at the point of ignition, the concentration of combustible gases has reached the lower flammability limit and has sufficient energy for ignition to occur $[38,42,127]$. The critical heat flux criterion represents the lowest value of constant heat flux under which ignition is observed. The critical heat flux criterion for ignition is unique in that it defines critical boundary conditions and is not a critical response or behavior of the substrate. These criteria are applicable to both smoldering and flaming ignition occurrences such that at higher incident heat fluxes, the maximum values for smoldering ignition approaches minimum values for flaming ignition. Bilbao et al. [38] have experimentally shown that for heat fluxes over $40 \mathrm{~kW} / \mathrm{m}^{2}$ and at surface temperatures above $300{ }^{\circ} \mathrm{C}$, spontaneous flaming ignition is observed and therefore can be considered as maximum heat flux and maximum surface temperature, respectively, for smoldering to occur. Similarly, Boonmee and Quintiere [43] have shown that as the incident heat flux decreases, the piloted flaming ignition mass flux for solid wood decreases and asymptotically approaches the theoretical glowing ignition mass flux of $1 \mathrm{~g} / \mathrm{m}^{2} / \mathrm{s}$ to $4 \mathrm{~g} / \mathrm{m}^{2} / \mathrm{s}$. Wessis et al. have shown that there is a wide range of values between $1 \mathrm{~g} / \mathrm{m}^{2} / \mathrm{s}$ and $10 \mathrm{~g} / \mathrm{m}^{2} / \mathrm{s}$ for mass flux at flaming ignition, dependent on material and 
environmental properties [105]. Melinek [128] has shown that the critical rate of emission of volatiles of the order of $6 \mathrm{~g} / \mathrm{m}^{2} / \mathrm{s}$ is a suitable criterion for the flaming ignition of wood.

Vermesi et al. [127] evaluated the solid-phase ignition criteria used in the literature and found that neither criteria are a consistent indicator of ignition. They suggested that the solid-phase criteria for nonpiloted ignitions under constant heat flux exposures are not easily applicable in cases with transient irradiation. Moreover, the characterization of smoldering activation is complicated since the ignition temperature is not a fundamental parameter of the fuel and there is no unique ignition temperature characteristic of a given material [129]. Smoldering activation temperature depends on several factors including the sample mass, heating rate of the material, surrounding gas atmosphere, porosity, sample configuration, and others [45, 104, 129]. Olhemiller's experiments on smoldering ignition of porous cellulosic insulation materials concluded that ignition occurs when heat generation per unit volume of the substrate fuel exceeded heat losses. Similarly, Boonmee and Quintiere [44] developed the energy balance criteria for glowing ignition of wood. They suggested that the glowing ignition occurred when the energy gain at the wood surface was greater than the energy loss and this was found to occur at an inflection point on wood surface temperature-time plot. The time to smoldering ignition has been detected by using thermocouples to detect a sharp rise in the temperature of the substrate [96]. The characteristic point of rapid temperature increase from $297{ }^{\circ} \mathrm{C}$ to $397{ }^{\circ} \mathrm{C}$ on the wooden sample surface was noted to be the moment when rapid exothermic oxidation occurred indicating the initiation of smoldering [45].

For determining smoldering ignition in wood, Gratkowski et al. [39] considered four criteria including 1) glowing of sample, 2) temperatures over $400{ }^{\circ} \mathrm{C}$ at the surface or within the sample, 3) evidence of smolder propagation wave, and 4) visual observation of decomposition of the sample and presence of residual white ash. Several researchers have reported glowing as a primary criterion for smoldering ignition while others verified smoldering combustion by post-test observation of significant consumption of the sample or the presence of residual white ash [41]. Continuous smoking which is indicative of sustained combustion within the pyrolyzing material has also been used as visual evidence of smoldering [21]. To identify different oxidation stages, Ronda et al. [104] monitored $\mathrm{CO} / \mathrm{CO}_{2}$ during the smoldering process. The highest production of $\mathrm{CO}$ was recorded at the beginning of the smoldering process, suggesting the importance of partial oxidation and pyrolytic processes.

It is important to note here that these criteria are appropriate for constant heat flux exposures and may not be applicable for wooden substrates exposed to smoldering embers. In this context, Hakes et al. [29] suggested that char progression beyond the areas not directly in contact with embers be considered as smolder spread in the substrate. For similar ember exposure experiments, Salehizadeh [31] used thermocouple temperature measurements within the wood samples to determine the onset of smoldering. A threshold temperature of $200{ }^{\circ} \mathrm{C}$ was set to represent smoldering ignition in wood. It was claimed that although the threshold temperature of $200{ }^{\circ} \mathrm{C}$ was much lower than what was typically considered for the onset of smoldering in wood, visual observations confirmed the initiation of smoldering process. 


\section{Experimental Studies of Ember Ignition of Structural Components}

Spotting fires result from complex interactions between the ember efficacy to ignite the fuel bed and ignition propensity of the recipient fuel [68]. As discussed earlier, the efficacy of embers to ignite the substrate depends on the mass and thermal characteristics of the embers discussed in Section 4 and physical and thermal properties of the substrate and surrounding environmental conditions including wind and moisture content discussed in Section 3. In this section, experimental studies describing ember ignition of structural components are reviewed and summarized.

\subsection{Real-Scale and Intermediate-Scale Experiments}

Several real-scale experiments studying ember ignitibility of residential and commercial structures have been conducted at the Insurance Institute for Business and Home Safety (IBHS) in South Carolina, USA. Quarles et al. studied ignition potential of decks [130], mulch [131], vents [132], and other building components including roofing and siding materials [133] subjected to ember exposure. The ember exposure capabilities at the IBHS research center consisted of five individual ember generators and array of fans to facilitate real-scale testing of structures. The ember generator design was based on a smaller scale device developed by the National Institute of Standards and Technology (NIST) Fire Research Division [133]. The real-scale testing was primarily conducted to evaluate potential vulnerabilities of a full-sized building, including roofing materials and designs, attic vents, siding materials, decking materials, and mulches exposed to a steady stream of embers for $10 \mathrm{~min}$. For testing of mulch products, the exterior walls adjacent to mulch were instrumented with thermocouples and heat flux sensors. Ember entry through vents and window screens was also tested. The testing indicated the following:

1. The vents positioned perpendicular to the direction of wind stream were more vulnerable to ember entry. The size of embers entering the attic was a function of the screen size of the mesh.

2. The untreated wood shake roof ignited and burned through the shingle layers and into the roof sheathing.

3. The vinyl gutters ignited in the presence of flammable debris, and flaming gutters contributed towards flame spread to the sides of the building.

4. The maximum heat flux on the exterior wall resulting from burning of combustible mulch that was ignited from the ember shower was approximately $80 \mathrm{~kW} / \mathrm{m}^{2}$, but this level was maintained only for a few seconds.

5. Ember ignition of vegetative fuel that accumulated on the deck occurred; however, the flaming from vegetative fuel was not able to ignite the deck boards.

The above experiments, however, did not quantify ignitability parameters such as time to ignition and ember flux.

Manzello et al. reported studies on ember ignition of several structural mock-ups including shingles [22], wooden decks [21, 28], fences [24], siding, roofing [122, 134, 135], walls, and glazing assemblies $[123,99]$. Full-scale mock-up assemblies were tested to investigate vulnerabilities of the components of structural assemblies to quantify ember exposures. Generally, the studies quantified ember exposure in terms of number and mass of embers per unit area per unit time. The thermal insult on the target was, however, not quantified in most 
studies. The authors further speculated correlation among moisture content, wood density, and time to ignition of substrates; however, no systematic conclusions were drawn or reported. Findings from these large-scale tests are summarized in [136], and qualitative observations are listed below:

1. The time to flaming ignition, defined as the time from when the first ember landed on the deck surface until the time when sustained flaming was observed, increased linearly with the mass of ember piles while the mass of ember pile required for flaming ignitions under a wind speed of $8 \mathrm{~m} / \mathrm{s}$ was considerably less compared with that required under a wind speed of $6 \mathrm{~m} / \mathrm{s}$.

2. The average time to flaming ignition of $437 \mathrm{~s}$ was the lowest for low-density cedar $\left(361 \mathrm{~kg} / \mathrm{m}^{3}\right)$ followed by $758 \mathrm{~s}$ for redwood $\left(437 \mathrm{~kg} / \mathrm{m}^{3}\right)$ and $934 \mathrm{~s}$ for Douglas fir $\left(534 \mathrm{~kg} / \mathrm{m}^{3}\right)$.

3. Ember accumulation was a function of wind speed and the profile of the roofing tile. In their bench-scale scaling tests, Kaye and Nguyen [137] have shown that ember removal increases and accumulation decreases with wind speed.

4. Cedar shake assemblies with no flame retardant treatment ignited easily from ember exposure for $20 \mathrm{~min}$, and this type of roofing materials generated more embers.

5. Vinyl siding melted and formed holes for the embers to reach the sheathing. Under high wind speed and in a dried state, the oriented strand board (OSB) sheathing that was placed behind the siding was ignited by embers and burned through its thickness. In the case of polypropylene sidings, although the polypropylene melted, no holes were formed and ignition of OSB sheathing was never observed.

6. Testing of eave configurations concluded that while the number of embers arriving at the vent increased with higher wind speed, the numbers arriving at the vent were far less than those accumulating at the base of the wall. The wall ignited at the base before the embers were able to accumulate and ignite the interior of the vents. In a separate study [123] on quantification of embers penetrating through the vents, the authors studied ignitability of combustible materials such as cotton, OSB, and shredded paper placed behind the vents. It was concluded that the mesh was not effective in preventing ignition of the chosen materials. Finer meshes reduced the ignitability of the materials but were unable to completely suppress ignition.

7. Ignition of wall assemblies in a re-entrant corner configuration was observed at the base of the wall, both in the absence and presence of combustible vegetative fuel.

8. Ignition of structural components was much easier in the presence of adjacent mulch.

9. Embers were capable of initiating smoldering ignition in wooden fences which transitioned into flaming ignition in the presence of wind.

Grishin [58] et al. conducted field experiments to investigate the effect of wildfires on wooden constructions including fences. They concluded that in the absence of embers, timber construction located at a distance of $5 \mathrm{~m}$ or more from the field fire did not ignite by radiative and convective thermal fluxes. They also suggested that the risk of fence ignition could be reduced by making the fences permeable to embers and by treating the wooden surface with flame retardant chemicals.

Real-scale experiments provide qualitative data via visual observations and reveal structural vulnerabilities and ignition probabilities under given ember exposure; however, these 
experiments rarely quantify thermal insult and burning behaviors in terms of ignition times and flame spread rates. Real-scale experiments can provide insight into the vulnerabilities of test fuel configurations, such as re-entrant corner or a crevice, to ember accumulation and subsequent ignition by the accumulated embers, compared to flat fuel substrates. Real-scale experiments, however, do not necessarily provide quantitative data that could be used in predictive models.

\subsection{Bench-Scale Experiments}

While real-scale experiments enable the testing of products in a real fire scenario, it is expensive (time and direct costs) to instrument such tests for the measurements of key thermal parameters such as temperatures or heat fluxes, and such measurements from full-scale experiments cannot typically be generalized outside the specific test conditions. Bench-scale experiments, on the other hand, facilitate the quantification of thermal properties with greater precision and often allow for replicate tests and therefore better understanding of the uncertainty and repeatability of results. The critical conditions established in these studies for the initiation of smoldering in structural wood could be useful in designing the appropriate test methods for assessing the smoldering ignition propensity of wooden substrates and modeling spotting fires on structural elements in WUI fires.

The ignition of a recipient substrate has been reported to occur with a correct combination of ember mass, fuel type, wind speed, and the contact area between the embers and the surface of the substrate. In this section, the studies that generated such data are reviewed and reported. Where available, relevant experimental details are also included.

McArthur and Lutton [109] examined the ignition of wooden structural mock-ups under typical "bushfire conditions". Ignitibility and flame propagation in mock-ups representing a deck/reentrant corner configuration formed by two walls or window frame and timber cladding were assessed. The ignitibility of wooden planks was assessed using both artificial (cribs) and realistic (combustible debris made of dried leaves and twigs) ignition sources. These ignition sources were placed individually on the test specimen and ignited using a torch flame. The extent of flame spread on the mock-up surface was used as a criterion for ignitability, and a rating system was developed for comparison. The authors concluded that ignition occurred readily in the re-entrant corner configuration with a free burning crib as the ignition source. The moisture content of the timber specimens significantly affected ignitibility such that increasing moisture content rendered the specimen more difficult to ignite. Less than $1 \mathrm{~g}$ of fuel was required to ignite a specimen with $5 \%$ moisture, $6.0 \mathrm{~g}$ for a specimen with $12 \%$ moisture, but the specimen with $17 \%$ was not ignited by the largest crib with combustible mass of $12 \mathrm{~g}$. No quantitative data such as time to ignition, duration of flaming, mass loss, or charring length in the wood specimens were reported.

Dowling [98] performed experiments to investigate the ignition of wood bridge members due to ember deposition. They burned wood cribs to generate embers which were then deposited into a $10 \mathrm{~mm}$ gap between the wood bridge members (deck plank and gravel beam). The mass of embers ( $7 \mathrm{~g}$ to $35 \mathrm{~g}$ ) generated was varied by altering the initial mass of the wood crib. It was observed that $7 \mathrm{~g}$ of embers in the $10 \mathrm{~mm}$ gap were able to produce smoldering ignition in the wood members. The study, however, did not report on the thermal characteristics of the embers or the extent of smoldering in the timber. 
Manzello et al. [21] investigated a range of conditions for glowing embers to ignite common building materials including plywood and oriented strand boards. The ignitibility of these materials was tested in a crevice configuration, and the angle between the two crevice components was varied from $60^{\circ}$ to $135^{\circ}$. The ignition of the substrate was found to occur with a correct combination of ember mass, fuel type, wind speed, and the contact area between the embers and the surface of the substrate. They reported that an individual ember was not capable of initiating combustion in a solid wooden substrate and that no ignitions were observed for an airflow of $1.3 \mathrm{~m} / \mathrm{s}$. However, intense smoke generation, defined as initiation of smoldering ignition, was reported when 4 embers were piled on the substrate. Ignition occurred only when test specimens were oven-dried, and no ignitions were observed for specimens with $11 \%$ moisture content.

Kasymov et al. [26, 107, 124] studied the ignition of solid wood samples by embers generated under laboratory conditions. To simulate the real wildfire scenario, the wood substrate was preheated up to a temperature of $220{ }^{\circ} \mathrm{C}$, and wind flows of $1 \mathrm{~m} / \mathrm{s}$ to $1.5 \mathrm{~m} / \mathrm{s}$ were applied. Simulated embers were produced by exposing pine bark and twigs of varying dimensions to gas burners. The authors defined the minimum total area of smoldering embers as the product of the number of embers and their characteristic area and used this parameter to compare the ignitibility of wood substrate. The minimum total area of smoldering embers to ignite flame retardant treated wood was found to be 3 times higher than that required to ignite untreated wood. However, the values for minimum smoldering area were not reported. A very large parameter space was investigated including the effects of size and number of embers, wind speed, temperature of heated air, and effects of flame retardant treatments on the ignitability of solid wood substrate. While many variables were explored, no strong correlations were made and reported in the papers. The thermal properties of embers were not quantified, and important flammability parameters, such as time to smoldering ignition, transition to flaming, and mass loss of the substrate were not reported.

Santamaria et al. [23] performed bench-scale experiments to systematically study the smoldering ignition in wooden substrates exposed to ember piles. They calculated the heat flux from laboratory-generated smoldering embers to an inert substrate and further assessed smoldering propensity of a wooden substrate exposed to the same of ember pile mass, thus estimating the amount of heat flux from smoldering embers to initiate smoldering in the wooden substrate. The conductive heat fluxes in both the inert substrate and the wooden substrate were calculated by measuring the temperature gradient in the substrates and by assuming one-dimensional conductive heat transfer with constant conductivity (independent of temperature) and negligible heat losses. The effects of airflow and moisture content were not examined in their study.

More sophisticated instrumentation was used by the research group at the University of Maryland to study the thermal characteristics of individual embers and piles of embers. They studied the critical conditions for ignition of structural materials using piles of smoldering embers [29, 31]. The repeatability and reproducibility of measurements as well as the production of smoldering ember piles were established in their studies. The study was further extended by Tao et al. [32] to examine the effects of types of embers and geometric formations of ember piles on spatial and temporal variations of heat fluxes on a flat substrate. 


\section{Existing Test Methods for Assessing Ignitability of Structural Components in WUI Settings and their Limitations}

In 2001 the International Code Council (ICC) recognized the need for a set of regulations for mitigating the hazard to property from wildland fire exposures and from adjacent burning structures. The first edition of the International Wildland-Urban Interface Code (IWUIC) was published in 2003 and was based on the data collected from tests and fire incidents, technical reports and mitigation strategies from around the world. At the national level, Australia and the US have respectively AS 3959 [138] and NFPA 1144 [139] that provide minimum requirements for new construction to reduce the potential of structure ignition from wildland fires. Very recently, the National Research Council of Canada was tasked with the development of a national WUI guide/code for Canada including new test methods to assess resilience of construction components in WUI communities. The AS 3959 refers to AS-NZ 1530.8.2 [140] for assessing the fire performance of building components and/or assemblies exposed to extreme bushfire conditions. The IWUIC and NFPA 1144 make references to the ASTM, NFPA, and UL standards (listed in Table 1) to provide requirements for materials, assemblies, and methods of construction.

The California Building Code adopted the ICC and made necessary amendments to include minimum standard requirements for structural components and assemblies exposed to flames and burning embers generated by wildland fire in Chapter 7A. The State Fire Marshall (SFM) testing standards described in the California Reference Standard Code Part 2 are summarized in Table 1 below. These standards, by far, have the most stringent requirements and were developed based on the knowledge gained from several post-WUI fire studies and numerous fire tests performed at the Forest Products Fire Research Laboratory at University of California, Berkeley. It is noted that standard test methods, e.g., the ASTM E119, using controlled gas-fired furnaces for assessing fire resistance of building components do not ensure their performance when exposed to sudden direct flame impingement or ember exposure under radiant heating conditions. Most SFM standards are designed to capture direct flame exposures.

Generally, most codes prescribe the use of non-combustible materials or ignition resistant materials for use in WUI areas. According to the ASTM E 136, a non-combustible material does not ignite or burn when exposed to heat or fire. The ASTM E136 describes a standard test method for assessing non-combustibility of building materials using a vertical tube furnace at $750{ }^{\circ} \mathrm{C}$. Materials are classified as non-combustible if the specimen meets any of the following requirements:

1. An individual test specimen does not ignite or exhibit flaming combustion during the first $30 \mathrm{~s}$ of the test.

2. If the specimen ignites and burns, the mass loss of the test specimen shall not exceed more than $50 \%$ of its original mass, and temperature of the specimen shall not increase more than $780{ }^{\circ} \mathrm{C}$.

3. The mass loss of the test specimen exceeds $50 \%$, but the temperature of the specimen does not exceed the temperature of the furnace during the 30 min test.

Generally, cement, ceramic, gypsum, stucco, metals (excluding aluminum which is characterized to have limited combustibility), mineral wool, rock wool, and glass are classified as non-combustible building materials. Composite materials can also qualify as noncombustible materials as long as the substrate material meets the above-mentioned 
requirements. Flame-retarded materials including wood and plastic are classified as combustible materials.

Ignition-resistant materials are defined as building materials that do not ignite or exhibit sustained flaming combustion in the presence of high wind and low moisture conditions. Although the ASTME 84 describes the standard test method to assess surface burning characteristics (flame spread) of building materials, this test method is specified by the code for assessing ignition-resistant materials. If the flame spread is considered as a series of consecutive ignitions, the test method can be presumably employed to assess ignition resistance of materials. For a material to qualify as ignition-resistant, it must have a maximum flame spread index (FSI) of 25 during the test period of $30 \mathrm{~min}$. The flame spread index indicates the relative rate at which flame will spread over the surface of a sample, as compared with flame spread on asbestos-cement board (rated zero) and on red oak (rated 100). The flame spread index of a sample is calculated as product of FSI of red oak (100) and the ratio of time required for flame to spread over $5.9 \mathrm{~m}(19.5 \mathrm{ft})$ of a red oak specimen to the time in which flame spreads on $5.9 \mathrm{~m}(19.5 \mathrm{ft})$ of the sample. Examples of ignition-resistant materials include all non-combustible building materials and flame-retardant treated wood and plastic. It is important to note that all non-combustible building materials are ignition-resistant but not all ignition-resistant materials are non-combustible. For example, most flame retardant treated wood and plastics can qualify as ignition resistant materials, but they do not classify as noncombustible.

If building materials are not ignition-resistant or are not classified as non-combustible materials, then the California Building Code calls for structural components or assemblies such as exterior walls, exterior windows, eaves and soffits, vents, decking, and roofs to meet the requirements of the SFM standards listed in Table 1. In addition to ignition resistance or noncombustibility, it is important that the exterior of the structure is capable of resisting entry of flying embers and should withstand radiant heat from wildland fire or nearby burning structures. 
Table 1. Standard test methods for assessing ignitability of structural components in WUI communities.

\begin{tabular}{|c|c|c|c|c|}
\hline $\begin{array}{l}\text { Structural } \\
\text { component }\end{array}$ & Standards & $\begin{array}{l}\text { Ignition } \\
\text { source/intensity/duration } \\
\text { (min) }\end{array}$ & $\begin{array}{l}\text { Test duration } \\
\text { (min) }\end{array}$ & Requirements/classifications \\
\hline $\begin{array}{l}\text { Non-combustible } \\
\text { Materials }\end{array}$ & ASTM E136 [141] & Vertical tube furnace & 30 & $\begin{array}{l}\text { No ignition } \\
\text { Mass loss < } 50 \% \\
\text { Temperature of specimen shall not } \\
\text { exceed } 750{ }^{\circ} \mathrm{C}\end{array}$ \\
\hline $\begin{array}{l}\text { Ignition resistant } \\
\text { materials }\end{array}$ & $\begin{array}{l}\text { SFM-12-7A-5 uses } \\
\text { ASTM E } 84 \text { [142] }\end{array}$ & Gas burner & $\begin{array}{l}10 \\
(30 \text { min for flame } \\
\text { retardant treated } \\
\text { wood })\end{array}$ & Flame spread index of $<25$ \\
\hline $\begin{array}{l}\text { Exterior wall } \\
\text { assembly (siding } \\
\text { and sheathing) }\end{array}$ & $\begin{array}{l}\text { SFM-12-7A-1 } \\
\text { (NFPA 285 [143], } \\
\text { ASTM E } 119 \text { [144], } \\
\text { ASTM E } 2707 \text { [145], UL } \\
\text { 263, ASTM E 1623) }\end{array}$ & Gas burner/150 kW/10 & 70 & $\begin{array}{l}\text { No flame penetration and no evidence of } \\
\text { glowing }\end{array}$ \\
\hline Exterior window & $\begin{array}{l}\text { SFM-12-7A-2 } \\
\text { (NFPA 257) }\end{array}$ & Gas burner/150 kW/8 & $\begin{array}{l}\text { Until flame } \\
\text { penetration occurs }\end{array}$ & $\begin{array}{l}\text { No flame penetration and no structural } \\
\text { failure during } 8 \text { min of flame application }\end{array}$ \\
\hline $\begin{array}{l}\text { Horizontal } \\
\text { projections } \\
\text { including eaves }\end{array}$ & $\begin{array}{l}\text { SFM-12-7A-3 } \\
\text { (ASTM E 2957 [146]) }\end{array}$ & Gas burner/300 kW/10 & 40 & $\begin{array}{l}\text { No flame penetration, no structural } \\
\text { failure, and no sustained combustion }\end{array}$ \\
\hline \multirow[t]{2}{*}{ Vents } & ASTM E 2886 & Embers/-/3 & 3 & \multirow{2}{*}{$\begin{array}{l}\text { No ignition of cotton } \\
\text { No flame penetration }\end{array}$} \\
\hline & ASTM E 2912 & Flames/ $300 \mathrm{~kW} / 10$ & 10 & \\
\hline \multirow[t]{2}{*}{ Decking } & $\begin{array}{l}\text { SFM-12-7A-4 } \\
\text { Part A: Under Deck } \\
\text { ASTM E } 2632\end{array}$ & Gas burner/80 kW/3 & 40 & $\begin{array}{l}\text { Heat release rate }<269 \mathrm{~kW} / \mathrm{m}^{2} \\
\text { No flaming or glowing combustion } \\
\text { No falling particles }\end{array}$ \\
\hline & $\begin{array}{l}\text { SFM-12-7A-4 } \\
\text { Part B: Burning brands } \\
\text { ASTM E } 2726\end{array}$ & $\begin{array}{l}\text { Class A wood crib/-/- } \\
\text { Class B wood crib/-/- } \\
\text { Wind speed: } 5.3 \mathrm{~m} / \mathrm{s} \pm 0.2 \\
\mathrm{~m} / \mathrm{s}\end{array}$ & $\begin{array}{l}\text { Not to exceed } 90 \\
\text { min }\end{array}$ & $\begin{array}{l}\text { No burn through } \\
\text { No sustained flaming or glowing } \\
\text { combustion }\end{array}$ \\
\hline
\end{tabular}




\begin{tabular}{|c|c|c|c|c|c|}
\hline $\begin{array}{l}\text { Structural } \\
\text { component }\end{array}$ & Standards & $\begin{array}{l}\text { Ignition } \\
\text { source/intensity/duration } \\
\text { (min) }\end{array}$ & $\begin{array}{l}\text { Test duration } \\
(\mathrm{min})\end{array}$ & \multicolumn{2}{|c|}{ Requirements/classifications } \\
\hline \multirow[t]{6}{*}{ Roof } & \multirow[t]{2}{*}{$\begin{array}{l}\text { ASTM E } 108 \\
\text { Flame spread test }\end{array}$} & $\begin{array}{l}\text { Gas burner/flame } \\
\text { temperature of } 760{ }^{\circ} \mathrm{C} / 10\end{array}$ & \multirow{5}{*}{$\begin{array}{l}\text { Not to exceed } 60 \\
\text { min }\end{array}$} & \multicolumn{2}{|c|}{$\begin{array}{l}\text { Class A and Class B } \\
\text { No flame spread beyond } 1.8 \mathrm{~m}(6 \mathrm{ft}) \text { for } \\
\text { Class A and } 2.4 \mathrm{~m}(13 \mathrm{ft}) \text { for Class B } \\
\text { roofs }\end{array}$} \\
\hline & & $\begin{array}{l}\text { Gas flame/ flame } \\
\text { temperature of } 704{ }^{\circ} \mathrm{C} / 4\end{array}$ & & \multicolumn{2}{|c|}{$\begin{array}{l}\text { Class C } \\
\text { No flame spread beyond } 4.0 \mathrm{~m}(13 \mathrm{ft})\end{array}$} \\
\hline & \multirow{3}{*}{$\begin{array}{l}\text { Intermittent flame } \\
\text { exposure test }\end{array}$} & Gas flame/15 cycles/2 & & Class A & \multirow{3}{*}{$\begin{array}{l}\text { No sustained flaming of the } \\
\text { deck }\end{array}$} \\
\hline & & Gas flame/8 cycles/2 & & Class B & \\
\hline & & Gas flame/3 cycles/1 & & Class C & \\
\hline & Burning brand test & $\begin{array}{l}\text { Class A wood crib/-/- } \\
\text { Class B wood crib/-/- } \\
\text { Class C wood crib/-/- }\end{array}$ & $\begin{array}{l}\text { Not to exceed } 90 \\
\text { min }\end{array}$ & \multicolumn{2}{|c|}{ No sustained flaming of the deck } \\
\hline
\end{tabular}




\subsection{Exterior Wall Assemblies}

The SFM-12-7A-1 specifies a test method for assessing the performance of exterior wall assemblies exposed to direct flames. The SFM-12-7A-1 test uses a $150 \mathrm{~kW}$ gas burner that is applied to the face of the test specimen $1.2 \mathrm{~m}(4 \mathrm{ft})$ wide $\mathrm{x} 2.4 \mathrm{~m}(8 \mathrm{ft})$ tall for $10 \mathrm{~min}$. The gas burner has nominal dimensions of $100 \mathrm{~mm}$ x $1000 \mathrm{~mm}$ (4 in x $39 \mathrm{in}$ ). Such exposure by flame impingement is determined by assessing the burning intensity of typical ornamental plants or similar vegetative fuel surrounding structures. The duration of exposure is based on field studies that indicate direct flame impingement for 10 min during a passing wildfire. The test specimen is monitored for $60 \mathrm{~min}$ following $10 \mathrm{~min}$ flame exposure to detect sustained smoldering in the test specimen. The wall assembly meets the requirements of the test if no flame penetration is observed through the wall assembly and there is no evidence of glowing combustion on the unexposed side of the assembly. The duration of observation $(70 \mathrm{~min})$ is critical since the persistence of sustained smoldering could transition into flaming combustion and lead to loss of the structure. The wall assembly is tested only for structural integrity and flame penetration. Wall construction materials such as concrete, fiber-cement siding, exterior fire-retardant treated wood siding, stucco, and masonry can resist the flame penetration for 10 min and meet the requirements of the SFM-12-7A-1 but may not qualify for fire resistance rating according to the ASTM E119. If sufficient heat is transferred through these materials, it is quite likely that the interior components of the wall may get overheated and may ignite and spread the fire. It is therefore necessary that the exterior wall assembly has a minimum of $1 \mathrm{~h}$ fire-resistant rating in addition to meeting the requirements of the SFM-12-7A-1. The California State Fire Marshal is also considering including a flame spread criterion, similar to the one required by the NFPA 285 standard, for assessing the fire performance of an exterior wall. Radiant heat exposure should also be considered in addition to the direct flame impingement test since thermal radiation occurs prior to the arrival of the flame front in WUI regions.

\subsection{Exterior Windows}

Exterior windows and skylights must comply with the requirements of the SFM-12-7A-2 standard. The test method uses a similar set up as described in the SFM-12-7A-1 except that the test specimen includes a window assembly (frame and glazing) and that the burner flame is applied for $8 \mathrm{~min}$. To be compliant with the standard, the window assembly must not exhibit structural failure and/or flame penetration during flame exposure. FEMA's (Federal Emergency Management Agency) [147] Home Builder's Guide to Construction in Wildfire Zones recommends laminated glass, tempered glass, low emissivity glass, fiberglassreinforced translucent glazing, and insulated glazing units for window glazing and metal or metal-clad wood for window frames. A number of tests performed at the University of California, Berkeley, have suggested that annealed glass, ceramic glass, and plastic glazing are not suitable for structures in WUI communities [148]. Particularly, ceramic glass, which is resistant to flames, has a high tendency to transmit radiant heat that could potentially lead to the ignition of the interior of the structure. Annealed glass is prone to structural failure when exposed to high temperatures. Plastic, including acrylic and polycarbonate, glazing panels can melt and deform during wildfire and hence are not recommended for structures in WUI communities. 


\subsection{Eaves and Horizontal Projections}

Generally, the construction materials for eaves, soffits, and other horizontal projections are not fire resistant. However, these structural components are susceptible to ignition by embers, direct flame impingement, and radiant heat. It is, therefore, necessary for these structural components to meet the requirements of the SFM-12-7A-3 standard especially if the structure happens to be in a high risk WUI zone, i.e., structures that are in close proximity to continuous wildland fuel. The test method described in the SFM-12-7A-3 uses a similar test set-up except that the supporting wall is made of non-combustible material and the heat release rate (HRR) of the gas burner is twice that is used in the SFM-12-7A-1. The distance between the top of the burner surface and the bottom of the eave assembly is approximately $2.1 \mathrm{~m}(82 \mathrm{in})$. The duration of the post-flaming exposure observation is reduced to $30 \mathrm{~min}$ from $60 \mathrm{~min}$ in the SFM-12-7A-1. The $300 \mathrm{~kW}$ square ( $305 \mathrm{~mm} \times 305 \mathrm{~mm}$ ) gas burner is designed to account for the heat release from ignitable siding on the exterior wall in addition to the burning adjacent vegetation. To meet the requirements of the test, the eaves or the materials used in the construction of horizontal projections shall not exhibit any evidence of flame penetration, structural failure, and glowing combustion during the 40 min test period.

The established $300 \mathrm{~kW}$ flaming exposure is based on the preliminary testing of siding materials. The subsequent testing on a range of cladding materials including plywood, oriented strand board, vinyl, and aluminum sidings have measured high heat release rates up to $500 \mathrm{~kW}$ [146]. It is likely that the eaves and soffits compliant with the SFM-12-7A-3 could fail in the presence of siding materials with high heat release rates. The exposure level for testing eaves and soffits might require additional review in order to be responsive to high heat release siding materials.

\subsection{Vents}

The ASTM E 2886 [149] describes the test methods to assess structural integrity of vents when exposed to ember showers and burner flames. The vents are exposed to an ember shower for approximately $3 \mathrm{~min}$ and to a direct flaming ignition source (with a heat release rate of 300 $\mathrm{kW} \pm 10 \mathrm{~kW}$ ) for $10 \mathrm{~min}$. Embers are generated by burning ten Class $\mathrm{C}$ brands (approximately $90 \mathrm{~g}$ ) and agitating burning embers against steel nuts and steel rods placed along the perimeter of the tumbler. Air is pulled through the vents to generate negative air pressure to suck the embers or the flames through the vent. Vents are exposed to embers for 3 min or until all the embers in the tumbler are extracted by exhaust fan. Smoldering and/or flaming ignition of cotton batting that is used as a combustible target is reported for the ember intrusion test. Failure of a test specimen is reported when sustained smoldering and/or flaming ignition of cotton batting is observed due to ember intrusion.

The ASTM E 2886 refers to the ASTM E 2912 [150] for the test apparatus and test procedure for assessing flame intrusion performance of the vents. The square gas burner for the direct flame impingement test is similar to the one described in the ASTM E 2257 [151] and is designed to simulate exterior fire sources including burning wood piles or ornamental vegetation, or both. The test specimen is assessed for flame penetration and optional insulation performance. No flame penetration or flaming ignition of cotton batting shall occur for the 
test specimen to pass the test. To pass the optional criteria of insulation, the maximum temperature on the unexposed side of the vent shall not exceed $380{ }^{\circ} \mathrm{C}$.

\subsection{Decks}

The SFM-12-7A-4 describes two test methods: Part A addresses under-deck flaming exposure (equivalent to the ASTM E 2632) and Part B addresses ember exposure on the decks (equivalent to the ASTM E 2726). The flaming ignition source in the under-deck test simulates the burning of combustible materials under the deck that are ignited by wildfire exposure. A square diffusion gas burner $(305 \mathrm{~mm} \times 305 \mathrm{~mm})$ is placed under the test specimen such that the nominal distance between the top of the burner and the bottom of the test specimen is 690 $\mathrm{mm} \pm 5 \mathrm{~mm}$. The $80 \mathrm{~kW}$ heat output of the gas burner and 3 min duration of flame application is based on the energy released by $1 \mathrm{~kg}$ of paper trash and the time it takes to burn the paper trash. For the acceptance criteria, the SFM-12-7A-4 standard specifies the maximum net peak heat release rate of $269 \mathrm{~kW} / \mathrm{m}^{2}$, whereas the equivalent ASTM E 2632 standard has no such requirement. The heat release rate is measured using oxygen consumption calorimetry. The upper limit of $269 \mathrm{~kW} / \mathrm{m}^{2}\left(25 \mathrm{~kW} / \mathrm{ft}^{2}\right)$ set in the SFM standard is an arbitrary value based on the extensive testing conducted during the development of the standard. The cut-off value was chosen to ensure that the attached structural components of the wall did not get involved in burning; however, the testing of several different decking materials had suggested that the effective net PHRR (defined as: peak HRR = (peak HRR in $\mathrm{kW}$-burner output in $\mathrm{kW}) /($ deck surface area)) remained below $70 \mathrm{~kW} / \mathrm{m}^{2}$ in [17] and varied between $80 \mathrm{~kW} / \mathrm{m}^{2}$ and $250 \mathrm{~kW} / \mathrm{m}^{2}$ in [152].

Before the development of the SFM-12-7A-4, the decking materials were tested in accordance with the UL 723/ASTM E 84. Recently, Fabian [152] reported the comparative analysis of results from two tests methods, viz., the UL 723/ASTM E 84 and the SFM-12-7A-4 Part A. He concluded that there was no correlation between Steiner Tunnel FSI ratings (UL 723/ASTM E 84) and effective net PHRR (SFM 12-7A-4 Part A Under-Deck Flame Test) such that the Class A Steiner Tunnel FSI rating did not guarantee compliance with the SFM-12-7A-a and vice versa. However, the study suggested that PHHR measured using cone calorimetry correlated with the effective net PHRR measured in the under-deck flame test and the PHRR from cone calorimeter test could be used to predict performance of decking materials in the SFM-12-7A-4 test.

Part B of the SFM-12-7A-4 standard requires testing of decks using Class A brands (total amount of starting fuel $=2000 \mathrm{~g} \pm 150 \mathrm{~g}$ ). The Class A brand is an arrayed stack of sticks which is made from 36 sticks of Douglas fir arranged in three layers of 12 sticks each. Ovendried sticks have nominal dimensions of $19 \mathrm{~mm}$ x $19 \mathrm{~mm}$ x $305 \mathrm{~mm}$. The final dimensions of the formed grid are $305 \mathrm{~mm} \times 305 \mathrm{~mm} \times 57 \mathrm{~mm}$. The brand thus formed is ignited using a gas burner with a flame temperature of $888^{\circ} \mathrm{C} \pm 28^{\circ} \mathrm{C}$. The brand is exposed to the flame for a total duration of 5 min during which the brand is rotated such that the top and bottom surfaces are exposed for $30 \mathrm{~s}$ each, followed by $45 \mathrm{~s}$ exposure of the four sides and $30 \mathrm{~s}$ exposure of top and bottom surfaces again. The burning brand is placed on the test specimen, and the fan is turned on to simulate wind speed of $5.3 \mathrm{~m} / \mathrm{s} \pm 0.2 \mathrm{~m} / \mathrm{s}$. The observations of flaming or glowing combustion and/or the formation of falling and flying embers are made during the 40 min test period. The test method simulates landing of flaming combustible material on the surface of the deck and assesses its combustibility and subsequent ability to ignite the adjacent wall. The equivalent ASTM E 2726 standard, however, has made a provision for selection of class of 
brand size depending on the severity of the test. The Class B brands are smaller in size (152 $\mathrm{mm} \times 152 \mathrm{~mm} \times 57 \mathrm{~mm})$ and mass $(500 \mathrm{~g} \pm 50 \mathrm{~g})$ and thus have less severe exposure as compared to the Class A brands.

Both parts of the decking test observe for structural failure, sustained glowing or flaming combustion, and the formation of flaming embers from decking material; however, the acceptance criteria does not relate to the ignition or contribution to the wall fire. Hasburgh et al. [17] measured the thermal exposure to the adjacent wall during both tests (under-deck and above-deck) and found that the heat flux at a distance of $152 \mathrm{~mm}$ (6 in) above the deck spiked between $15 \mathrm{~kW} / \mathrm{m}^{2}$ and $25 \mathrm{~kW} / \mathrm{m}^{2}$. The highest heat flux on the wall was measured during the application of the ignition source (a propane burner for the under-deck test and burning brands for the above-deck test), and very little or no contribution from the burning of the decking material was noted.

\subsection{Roofs}

The test methods described in the ASTM E 108 [153] define the performance of roofing materials when subjected to specific fire exposures. Roofing materials are classified as Class A, Class B, and Class C depending on the severity of fire exposure. Three types of fire exposures include intermittent flame exposure, direct flame impingement, and ember exposure. An average flame temperature of $760{ }^{\circ} \mathrm{C} \pm 28^{\circ} \mathrm{C}$ is specified for the Class $\mathrm{A}$ and Class B roofs whereas an average temperature of $704^{\circ} \mathrm{C} \pm 28^{\circ} \mathrm{C}$ is used for the Class $\mathrm{C}$ roofs. For the flame spread test, the gas flame is applied for a period of $10 \mathrm{~min}$ for the Class A and Class B roofs, and the flame application time for the Class $\mathrm{C}$ roofs is $4 \mathrm{~min}$. For the intermittent flame tests, flame is applied for 15, 8, and 3 times for the Class A, Class B and Class C roofs respectively. The flame application times for each cycle is 2 min for the Class A and Class B roofs and $1 \mathrm{~min}$ for the Class $\mathrm{C}$ roofs. The flame off times during each cycle is $2 \mathrm{~min}$ for all classes of roofs. For the burning brand tests, the roofs are classified based on the type of brands used for testing. The original masses for the Class A, Class B and Class $\mathrm{C}$ brands are specified as $2000 \mathrm{~g} \pm 150 \mathrm{~g}, 500 \mathrm{~g} \pm 50 \mathrm{~g}$, and $9.25 \mathrm{~g} \pm 1.25 \mathrm{~g}$ respectively. An air current of $5.3 \mathrm{~m} / \mathrm{s} \pm$ $0.2 \mathrm{~m} / \mathrm{s}$ is applied to all the roof tests except for flying brand test where the air current is increased to $5.4 \mathrm{~m} / \mathrm{s}$. In all the tests, observations are recorded for the appearance of sustained flaming and flame penetration through the roofing deck, the generation of flaming or glowing embers, and the structural integrity of the test specimen.

In general, structural components and assemblies are mostly tested for structural integrity when exposed to direct flames and/or embers. None of these tests, excluding the firebrand test for decks and roof, include a wind component which is often associated with wildfires. As discussed earlier, wind plays a critical role in the transition of smoldering to flaming. Moreover, most of the standard test methods are qualitative and do not make quantitative measurements. 


\section{$7 \quad$ Potential Candidates for Surrogate Ignition Sources}

In this section, the surrogate ignition sources that have been studied in the published literature have been identified, and the data reported in the literature has been analyzed to characterize smoldering ignition in fuels related to wildfires. Several attributes of the desirable surrogate ignition sources are identified and reported. Ideally, a surrogate ignition source should be easyto-use, quantifiable, and capable of establishing conditions for self-sustained smoldering. The ignition (e.g., heating and oxygen availability) conditions induced by a surrogate ignition source should be repeatable and similar to those created by real piles of embers found in WUI environments.

In the early 1980s Olhemiller [129] used flat planar and tubular wire-like heaters as surrogate ignition sources to simulate light fixtures and electrical conductors that generated heat in the attic and were in constant contact with cellulosic insulation. Flat plate heaters were made by using a long, thin heating element, shaped into a raster-scan-like pattern (with less than $25 \mathrm{~mm}$ spacing) and sandwiched between two brass plates. The tubular heater was made by concentrically housing a heating element in a copper tube of $4.8 \mathrm{~mm}$ diameter. Both designs provided good temperature uniformity $\left( \pm 1^{\circ} \mathrm{C}\right.$ except at the edges) and heating times to reach typical set-point temperatures spanned between $12 \mathrm{~min}$ and $14 \mathrm{~min}$. The heater sources were coated with a thin layer of colloidal graphite paint to provide a reproducible surface emissivity. These surrogate ignition sources with different shapes were used in variety of configurations to study smolder initiation in cellulosic insulation. Minimum ignition temperatures were measured, and the results showed that the geometry of the heat source had significant influence on the smoldering ignition temperature. The time to smoldering ignition, however, was not measured. The study concluded that the larger the size of the ignition source, the lower the ignition temperature. It was shown that the minimum heat source temperature necessary to cause smoldering ignition in cellulosic insulation could be varied by at least $150{ }^{\circ} \mathrm{C}$ just by varying the heat source geometry. The author attributed this to the rate of heat losses (due to change in the configuration) and heat generation in the porous insulation.

Grishin et al. [112] determined the time to smoldering ignition of porous vegetative fuel using heated nichrome coil. A heated nichrome coil was used as a surrogate for smoldering twigs, cigarettes, and a burning match. A $1.5 \mathrm{~mm}$ diameter coil was formed by densely winding nichrome wire of $0.15 \mathrm{~mm}$ diameter. The coil was $20 \mathrm{~mm}$ long with a resistance of $23 \Omega$. The coil was heated by a controlled electrical supply to obtain temperatures in the range of $425^{\circ} \mathrm{C}$ to $1025^{\circ} \mathrm{C}$. Within the scope of the study, the authors were able to determine the power required for minimum ignition time of the fuel. They also reported that the ignition times became almost constant but never equaled to zero at any higher power.

Pitts [154] used a heated copper plate $(102 \mathrm{~mm} \times 102 \mathrm{~mm})$ to study smoldering ignition of porous cellulosic fuels. The heated copper plate was used to simulate heated exhaust surfaces of outdoor power equipment that could potentially ignite typical organic outdoor fuels. The copper plate was heated by 4 cartridge heaters embedded in it. The heated plate was placed in contact with porous fuel such that the dominant mode of heat transfer was conduction. Such electrical resistance heaters are easily controllable in terms of power output. Cartridge heaters consist of electrical resistance wiring inside a cylindrical housing. Applying power results in a temperature distribution along the length of the cartridge, with the center being hotter than the ends. The temperature of the copper plate was monitored using three type $\mathrm{K}$ thermocouples tapped in the plate. The copper plate was heated up to $525^{\circ} \mathrm{C}$ at which temperature the time 
to ignition for most fuels tested was within few seconds. The measured ignition times for various fuels showed exponential dependence on the temperature of the heated plate.

In an attempt to gain insights into the processes that govern the ignition of porous fuel beds by embers, Blunck and Bean [155] used a surrogate ember to ignite wood shavings. A $250 \mathrm{~W}$, $6.35 \mathrm{~mm}$ diameter, and $51 \mathrm{~mm}$ long cartridge heater was used as a surrogate for an ember. The temperature of the cartridge was continually recorded using a type-K thermocouple attached to the top of the cartridge heater and was held to within $\pm 6 \%$ of the set point using PID (proportional integral derivative) controller. The cartridge heater temperatures were varied between $600^{\circ} \mathrm{C}$ and $750{ }^{\circ} \mathrm{C}$, and the time to ignition was recorded using a photodiode to capture the lowering of the cartridge heater and the flames resulting from the ignition event.

Santamaria et al. [23] used an electric strip heater to simulate a smoldering ember pile on wood. The strip heater measured $130 \mathrm{~mm}$ x $45 \mathrm{~mm}$ with a heating area of $45 \mathrm{~mm}$ x $45 \mathrm{~mm}$. The heater was clamped to the wood samples using steel C-type clamps. The electrical heater provided a power of $150 \mathrm{~W}$ at $120 \mathrm{~V}$. A voltage variator or variac was used to vary the electrical supply voltage between $60 \mathrm{~V}$ and $120 \mathrm{~V}$. In this study and for the very first time, the authors attempted to calculate the heat flux from the surrogate ignition source onto the inert and also on the wooden substrates. At $60 \mathrm{~V}$, the heat flux provided by the heater was not sufficient to initiate charring in the wood. Charring was observed at $90 \mathrm{~V}$, but the smoldering process was not self-sustained despite heating for $30 \mathrm{~min}$. At $90 \mathrm{~V}$ supply to the heater, the calculated heat flux at $3 \mathrm{~mm}$ depth in the wooden substrate was $10 \mathrm{~kW} / \mathrm{m}^{2}$, whereas a maximum heat flux of $5 \mathrm{~kW} / \mathrm{m}^{2}$ was measured in the inert substrate. The lower heat flux in the inert substrate was attributed to lower thermal inertia of the inert substrate (vermiculite) resulting in lower stored energy compared to wood. The heat flux values calculated for the wooden substrate were comparable to but slightly lower than those reported by Hakes et al. [29], Salehizadeh [31], and Tao et al. [32] with real ember piles. The lower heat flux values could be attributed to absence of wind in the case of Santamaria's experiments.

In the limited number of experiments, sustained smoldering was not achieved with the electrical heater. The authors reported that the separation between the heater and the wood occurred due to shrinkage, i.e. decomposition, of the sample that decreased the efficiency of the conductive heat transfer. It also impacted the development of smoldering combustion at the surface of the sample since air currents increased convective losses but also increased oxygen supply which speeded up the oxidative reaction. The study showed that the heater allowed for a closer study of ignition by conduction of wood but that it constrained the oxygen supply at the surface (since it occupies the total surface of contact) and might prevent smoldering ignition at lower heat fluxes. The strip electric heater used by Santamaria and the heated copper plate used by Pitts have major disadvantage of restricted air supply at the smoldering front as opposed to characteristic porous ember piles that allows for more oxygen supply facilitating increased reaction rates or increased cooling of the smoldering surface and therefore increased heat losses from embers.

It is important to note here that electrical resistance heaters are capable of initiating smoldering ignition in both porous vegetative substrates and solid wooden substrates. These heaters are easy to control in terms of power output. Two heating modes can be examined. First, the heater power is controlled so that the heater/substrate interface temperature is maintained constant. The heater is powered to generate a peak heater/substrate interface temperature comparable to the peak value measured for embers. Generally, such experiments with a 
surrogate ignition source typically seek to identify the lowest temperature of the ignition source or the heat flux to the substrate and the time to ignition. Second, the supplied power is kept constant. The initial power and duration of heating can be obtained from experiments similar to those performed by Hakes et al. [29], Salehizadeh [31], and Tao et al. [32]. The shape and area under the temperature/time curve for a pile of embers on an inert substrate can be matched for the heater/inert substrate experiments to determine initial power and duration of heating.

Heated metal spherical balls as surrogate ignition sources simulating metal particles from clashing power-lines or hot metal particles generated by machines, grinding, and welding have been reported by Fernandez-Pello et al. [156] and summarized in [116]. Typically, spherical metal balls of varied dimensions $(2 \mathrm{~mm}$ to $11 \mathrm{~mm}$ ) were pre-heated in a furnace and transported directly on the porous cellulosic fuels to observe if flaming ignition or smolder ignition occurred. Typical temperatures ranged from $575^{\circ} \mathrm{C}$ to $1100{ }^{\circ} \mathrm{C}$. The thermal properties of the material (type of metal) did not have a significant effect on ignition. For all the metals used, the temperature required for ignition decreased with increasing particle diameter. Their data suggested that for large diameter particles, ignition was primarily dependent on particle surface temperature and for small diameter particles, ignition was a function of both mass and temperature. Krause and Schmidt [118] highlighted that the ignition sources had to satisfy certain criteria according to the energy stored therein to successfully ignite a bulk material. These criteria might vary between different substrates in addition moisture content. While the spherical particles were capable of initiating ignition in porous cellulosic substrates, it is difficult to envisage the ignition of solid wood substrates using such metal particles or cylindrical rods.

It is clear from the above studies that preheated spherical metal balls and tubular electric resistance heaters are suitable as surrogate ignition sources for porous fuels. Such ignition sources in discrete forms may not be appropriate for heating flat wooden substrates or may not be representative of ember piles since the contact area between the substrate and an individual metal ball or cartridge heater is very small. The area of intimate contact at the surface takes place only at the crest of curvature between the spherical ball or cartridge heater and the flat substrate and is only a small fraction of the nominal area. Moreover, the heat losses from spherical metal balls or tubular electric heaters to the surrounding may exceed net heat flux to the substrate, and self-sustained smoldering combustion in a solid wooden substrate may not occur. For ember piles, the surrogate ignition source should have a minimum contact area with the substrate that is equivalent to the area of a typical pile of embers. Experimental studies $[19,60]$ have reported pile areas between $40 \mathrm{~cm}^{2}$ to $80 \mathrm{~cm}^{2}$ for initiation of smoldering in solid wood substrates. The studies, however, do not report the bulk density of ember piles.

For a reactive ignition source such as an ember there can be thermal interaction with the substrate, resulting in the acceleration of the ignition process. There will be some thermal interaction for a non-reactive source, but it is likely to be different in character. This difference needs to be determined experimentally in order to relate the ignition performance of surrogate ignition sources and embers on wooden substrates. 


\section{$8 \quad$ Summary and Future Work}

This extensive literature review has indicated that previous works exist that focus discretely on ember generation and ember characterization, the ignition of wood, WUI exposures, or on other factors affecting the ignitability of wood. This review paper is unique in that it provides information on all these topics organized in systematic manner with a focus on the ignitibility of structural wood products exposed to embers during wildland fires. Additionally, this study has reviewed several surrogate ignition sources that are used to assess the smoldering propensity of wooden substrate exposed to smoldering embers.

Several case studies on structural ignitions in WUI communities have shown that indoor structural ignitions in WUI communities occur due to ember intrusion through eaves, attic vents, or openings formed in the structures due to the combined effects of radiant heat and high winds. In addition to ember exposures, many large-scale and intermediate-scale experiments have shown that embers tend to accumulate externally on solid substrates, particularly into gaps or re-entrant corner spaces. When lodged in such configurations, the heat losses from the embers to the environment are minimal and, in the presence of an increased airflow, heat production increases in the reaction zone of the ember pile, which may cause glowing ignition of the substrate and, in some cases, transition to flaming ignition. Such structural ignitions have been observed long after flaming fire has passed through WUI zones. Since wood and wood products are commonly used in US residential structures, they present ideal fuels for the occurrence of self-sustained smoldering in WUI settings.

Previous studies have characterized the onset of smoldering ignition by defining an ignition temperature. The surface temperature at the onset of smoldering ignition has been reported from $270{ }^{\circ} \mathrm{C}$ up to $400{ }^{\circ} \mathrm{C}$ depending on the incident heat flux. These studies have indicated that the surface temperature at ignition depends not only on the substrate but also strongly on the experimental conditions (irradiation and sample configuration) and the instrumentation used to measure the temperature. Experimental investigations of wood smoldering in response to direct contact heating from embers have shown that the contact between the embers and the substrate is critical in determining the mode of heat transfer and the probability of ignition. If the contact between the embers and the substrate is fairly good, heat transfer is most likely to occur via conduction. However, if the contact between the embers and the substrate is not perfect, heat transfer is more likely to occur via radiation and/or convection.

For determining the smoldering ignition in wood, researchers have considered different criteria including 1) glowing of the sample, 2) observation of temperatures over $400{ }^{\circ} \mathrm{C}$ at the surface or within the sample, 3) evidence of a smolder propagation wave, 4) a characteristic point of rapid temperature increase from $297{ }^{\circ} \mathrm{C}$ to $397{ }^{\circ} \mathrm{C}$ on the surface of wood, 5) visual decomposition and presence of residual white ash, 6) continuous and excessive smoking, and 7) excessive production of $\mathrm{CO}$ during pyrolysis.

A number of studies have reported on the effects of moisture content and wind speed on the smoldering ignition of a wooden substrate. Reviews on the role of moisture content on burning behavior of solid wood have generally shown that the samples containing moisture have delayed ignition, increased ignition temperature, and reduced smoldering velocity. However, a single critical moisture content value does not exist, and it has been shown to depend on the type of fuel and the size of the ignition source. Considering the atmospheric conditions during wildfires, low relative humidity values (5\% to $10 \%)$ in WUI regions suggest that the testing 
of oven dry samples represents the worst-case scenario. Previous studies on the effects of wind generally concluded that airflow had two competing effects on the smoldering combustion of fuel substrate. The increased supply of oxygen could enhance pyrolysis resulting in early ignition but increased airflow could also lower the surface temperature and dilute flammable gas mixtures, thereby delaying ignition. However, previous bench-scale or intermediate-scale laboratory studies have only explored wind speeds up to $5.5 \mathrm{~m} / \mathrm{s}$. Wind speeds in the range of $8 \mathrm{~m} / \mathrm{s}$ to $25 \mathrm{~m} / \mathrm{s}$ have been typically recorded during wildfires. It is not known if the effects of lower wind speeds could be extrapolated to higher wind speeds.

A review of the existing test methods for assessing the ignitability of structural components and assemblies indicates that the existing State Fire Marshall (SFM) standard test methods have direct flaming exposures with a maximum heat output of $300 \mathrm{~kW}$ with no wind and no radiant heat exposure. Radiant heat and exposure to wind and smoldering ignition sources should also be considered since thermal radiation occurs prior to the arrival of the flame front in WUI regions and high wind conditions are often associated with wildfires. Moreover, most building codes prescribe for non-combustible construction materials to be used in high risk WUI regions, i.e., the material shall not ignite when exposed to furnace temperature of $750{ }^{\circ} \mathrm{C}$. However, in these tests, ignition is defined as flaming, not smoldering, and samples that do ignite can still be defined as non-combustible if they lose less than $50 \%$ of their initial mass during the test. Under such exposure conditions, materials or construction assemblies designated as non-combustible can fail or present a smoldering ignition risk in real WUI fires. It is therefore necessary to develop a standard test method to assess the ignition resistance of wooden structural components to the heating conditions of real ember piles. An important step in developing such a test method is to establish a surrogate ignition source that is easy-to-use, quantifiable, and capable of establishing conditions for self-sustained smoldering.

A review of literature on potential surrogate ignition sources has shown that electrical resistance heaters are capable of initiating smoldering ignition in solid wooden substrates and their power output (and thus applied heat flux to the substrate) can be controlled. Electric heaters can be powered to generate heating conditions comparable to those measured for piles of real embers. However, direct application of electric strip heaters or heated plates to a substrate may restrict air supply at the smoldering front, as compared to porous ember piles. The impact of this change on oxygen supply and thus smoldering reaction rates must be explored.

Future experiments will explore the use of electric heaters as surrogate ignition sources for smoldering embers. The power supplied and duration of heating can be designed to match conditions measured in previous experiments using real ember piles. Preliminary experimental measurements will assess whether smoldering ignition is developed, and if so, the heating times required will be recorded. The very first step, however, would be to demonstrate the equivalence in heating between the selected surrogate ignition source and real embers. Dimensional analysis will be used to identify key parameters controlling material response under these heating conditions. It is expected that the use of surrogate ignition sources will provide a robust, accurate, and efficient approach to validate the performance of computational models designed to quantitatively predict the smoldering behavior of a combustible solid based on simulation of the chemical and physical mechanisms controlling this behavior and knowledge of the material's thermophysical properties. Further, when fully validated to capture the controlling mechanisms of smoldering ignition, such an experimental configuration 
may offer a valuable screening tool to evaluate the smoldering propensity of wood-based materials and products used in the WUI. 


\section{References}

[1] Housssami ME, Mueller E, Thomas JC, Simeoni A, Filkov A, Skowronski N, Gallagher $\mathrm{M}$, and Kermens. Experimental procedures characterizing firebrand generation in wildland fires. Fire Technology (2016)52: 731-751.

[2] Cohen JD. What is the wildland fire threat to homes? In: Thompson Memorial Lecture, April 10, 2000 School of Forestry, Northern Arizona University, Flagstaff, AZ. http://www.fs.fed.us/rm/pubs_other/rmrs_2000_cohen_j003.pdf.

[3] Cohen J. An Analysis of wildland-urban fire with implications for preventing structure ignitions. https://www.eenews.net/assets/2019/01/08/document_gw_02.pdf

[4] Manzello S and Quarles SL. Special section on structure ignition in wildland-urban interface fires. Fire Technology (2017) 53; 425-427.

[5] Quarles SL. Vulnerabilities of buildings to wildfire exposures. Article in Surviving Wildfire, August 2019. https://surviving-wildfire.extension.org/vulnerabilities-ofbuildings-to-wildfire-exposures/

[6] Maranghides A and Mell W. Framework for addressing the national wildland urban interface fire problem-Determining fire and ember exposure zones using a WUI hazard scale. NIST Technical Note 1748. January 2013.

http://dx.doi.org/10.6028/NIST.TN.1748

[7] Babrauskas V. Firebrands and embers. In Encyclopedia of Wildfires and WildlandUrban Interface (WUI) Fires. S.L. Manzello (ed.) https://doi.org/10.1007/978-3-319$\underline{51727-8 \quad 3-1}$

[8] Koo E, Pagni PJ, Weise DR, and Woycheese JP. Firebrand and spotting ignition in large-scale fires. International Journal of Wildland Fire (2010)19; 818-843.

[9] Manzello SL, Suzuki S., Gollner MJ. And Fernandez-Pello AC. Role of firebrand combustion in large outdoor fire spread. Progress in Energy and Combustion Science (2020) 76;100801. https://doi.org/10.1016/j.pecs.2019.100801

[10] Mell WE, Manzello SL, Maranghides A, Butry D, and Rehm RG. The wildland-urban interface fire problem-current approaches and research need. International Journal of Wildland Fire (2010) 19: 238-251.

[11] Quarles SL, Valachovic Y, Nakamura GM, Nader GA, and Lasaux MJ. Home survival in wildfire-prone areas: Building materials and design considerations. University of California Agriculture and Natural Resources, Publication 8393. May 2010. https://escholarship.org/content/qt4vt8w5qk/qt4vt8w5qk.pdf?t=p1zfsl

[12] Fact sheet: wildland-urban interface building codes. California Department of Forestry and Fire Protection, May 2007. Available at http://www.fire.ca.gov/fire_prevention/downloads/BSR_fact_sheet.pdf

[13] Manzello S and Quarles SL. Summary of Workshop on Structure ignition in WildlandUrban Interface (WUI) Fires. NIST Special Publication 1198 (2015). http://dx.doi.org/10.6028/NIST.SP. 
[14] Santoso MA, Christensen EG, Yang J, and Rein G. Review of the transition from smouldering to flaming combustion in wildfires. Frontiers in Mechanical Engineering (2019)5; 49, 1-20.

[15] Pagni PJ. Causes of the 20 October 1991 Oakland Hills Conflagration. Fire Safety Journal (1993) 21; 331-339.

[16] Gollner MJ. Pathways to fire spread in the wildland urban interface (WUI). In Summary of workshop on structure ignition in wildland-urban interface. September 2015. 1198 http://dx.doi.org/10.6028/NIST.SP.

[17] Hasburgh LE, Zelinka SL, and Stone DS. Laboratory investigation of fire transfer from exterior wood decks to buildings in the wildland-urban interface. Fire Technology (2017) 53: 517-534. DOI: 10.1007/s10694-016-0588-0

[18] Pellegrino JL, Bryner NP, and Johnsson EL. Wildland-Urban Interface Fire Research Needs, Workshop Summary Report. NIST Special Publication 1150, May 2013. http://dx.doi.org/10.6028/NIST.SP.1150.

[19] Manzello SL, McAllisterS, Suzuki S, Blanchi R, Pastor E, and Ronchi E. Large Outdoor Fires and the Built Environment (LOF\&BE): Summary of Workshop at Interflam 2019. NIST SP 1241. August 2019. https://doi.org/10.6028/NIST.SP.1241

[20] Waterman TE, and Takata AN. Laboratory study of ignition of host materials by firebrands. Final Technical Report Project J6142-OCD Work Unit 2539A. June 1969.

[21] Manzello SL, Park SH, and Cleary TG. Investigation on the ability of glowing firebrands deposited within crevices to ignite common building materials. Fire Safety Journal (2009) 44; 894-900.

[22] Manzello SL, Cleary TG, Shields JR, and Yang JC. Urban-Wildland Fires: On the ignition of fuel beds by firebrands. Fire and Materials (2006) 30: 77-87.

[23] Santamaria S, Kempna K, Thomas JC, Houssami M E, Mueller E, Kasimov D, Filkov A, Gallagher MR, Skowronski N, Hadden R, and Simeoni A. Investigation of structural wood ignition by firebrand accumulation. In proceedings of The First International Conference on Structural Safety under Fire \& Blast, At Glasgow, Scotland, UK. September 2015.

[24] Suzuki S, Johnsson E., Maranghides A, and Manzello SL. Ignition of wood fencing assemblies exposed to continuous wind-driven firebrand showers. Fire Technology (2016) 15(4); 1051-1067.

[25] Manzello SL, Suzuki S, and Daisaku Nii. Full-scale experimental investigation to quantify building component ignition vulnerability from mulch beds attacked by firebrand showers. Fire Technology (2017) 53 (2); 535-551.

[26] Kasymov D and Paletsky A. Effect of a fire retardant on the ignition of pine wood exposed to smoldering particles of pine bark, EPJ Web of Conferences (2017) 159; 00026. DOI: 10.1051/epjconf/201715900026.

[27] Suzuki S and Manzello SL. On the development and characterization of a reduced scale continuous feed firebrand generator. Fire Safety Science 10: 1437-1448. 
[28] Manzello SL, and Suzuki S. Exposing decking assemblies to continuous wind-driven firebrand showers. In proceedings of the $11^{\text {th }}$ International Symposium, International Association for Fire Safety Science, (2013) pp 1339-1352.

[29] Hakes RSP, Salehizadeh H, Weston-Dawkes MJ, and Gollner MJ. Thermal characterization of firebrand piles. Fire Safety Journal (2019) 104; 34-42. https://doi.org/10.1016/j.firesaf.2018.10.002

[30] Kim DK, and Sunderland PB. Fire ember pyrometry using a color camera. Fire Safety Journal (2019) 106; 88-93. https://doi.org/10.1016/j.firesaf.2019.04.006

[31] Salehizadeh H. Critical Ignition Conditions of Structural Materials by Cylindrical Firebrands. (2019) Masters Thesis, University of Maryland.

[32] Tao Z, Bathras B, Kwon B, Biallas B, Gollner M, and Yang R. Effect of firebrand size and geometry on heating from a smoldering pile under wind. Fire Safety Journal. https://doi.org/10.1016/j.firesaf.2020.103031

[33] Urban JL, Vicariotto M, Dunn-Rankin D and Fernandes-Pello CA. Temperature measurement of glowing embers with color pyrometry. Fire Technology (2019) 55; 1013-1026. https://doi.org/10.1007/s10694-018-0810-3

[34] Bearinger ED, Hodges JL, Yang F, Rippe CM, Lattimer BY. Localized heat transfer from firebrands to surfaces. Fire Safety Journal (2020) https://doi.org/10.1016/j.firesaf.2020.103037

[35] Atreya A, Carpentier C, Harkleroad M. Effect of sample orientation on piloted ignition and flame spread. Fire Safety Science -Proceedings of the first international symposium. Hemisphere, Washington, 1986, pp 97-109.

[36] Janssens M. Piloted ignition of wood: A review. Fire and Materials (1991)15; 151167.

[37] Shen DK, Fang MX, and Chow WK. Ignition of wood-based materials by thermal radiation. International Journal on Engineering Performance-Based Fire Codes (2006) 8 (2); 69-83.

[38] Bilbao R, Mastral JF, Aldea ME, Ceamanos J, and Betran M. Experimental and theoretical study of the ignition and smoldering of wood including convective effects. Combustion and Flame (2001) 126; 1363-1372.

[39] Gratkowski MT, Dembsey NA, and Beyler CL. Radiant smoldering ignition of plywood. Fire Safety Journal (2006) 41; 427-443.

[40] Schaffer EL. Smoldering initiation in cellulosics under prolonged low-level heating. Fire Technology (1980)16(1); 22-28.

[41] Swann J, Hartman J, and Beyler C. Study of radiant smoldering ignition of plywood subjected to prolonged heating using the cone calorimeter, TGA, and DSC. Fire Safety Science- proceedings of the 9th international symposium, pp.155-166. Doi: 10.3801/IAFSS.FSS.9-155.

[42] Yang L, Guo Z, Ji J, and Fan W. Experimental study on spontaneous ignition of wood exposed to variable heat flux. Journal of Fire Sciences (2005) 23; 405-416. 
[43] Boonmee N, Quintiere JG. Glowing and flaming autoignition of wood. In: Twentyninth Symposium (international) on combustion. The Combustion Institute; 2002. p. 289-96.

[44] Boonmee N, Quintiere JG. Glowing ignition of wood: the onset of surface combustion. In: Thirtieth symposium (international) on combustion. The Combustion Institute; 2004.

[45] Fangrat J, Hasemi Y, Yoshida M, and Hirata T. Surface temperature at ignition of wooden based slabs. Fire Safety Journal (1996); 249-259.

[46] Kuznetsov VT and Filkov AI. Ignition of various wood species by radiant energy. Combustion, Explosion, and Shock Waves (2011) 47 (1); 65-69.

[47] McAllister S, Critical mass flux for flaming ignition of wet wood. Fire Safety Journal (2013) 16; 200-206. https://doi.org/10.1016/j.firesaf.2013.09.002

[48] Lardet P, Georges V, Terrei L, and Nichane M. An engineering model for ignition and extinction of wood flames using bench-scale data. Journal of Physics: Conference Series 1107 (2018). Doi: 10.1088/1742-6596/1107/3/032005.

[49] Moghtaderi B, Novozhilov V, Fletcher DF, and Kent JH. A new correlation for benchscale piloted ignition data of wood. Fire Safety Journal (1997) 29: 41-59.

[50] McAllister S and Finney M. Autoignition of wood under combined convective and radiative heating. Proceedings of the Combustion Institute (2017)36: 3073-3080.

[51] Steckler KD, Evans DD, and Snell JE. Preliminary Study of the 1991 Oakland Hills Fire and Its Relevance to Wood-Frame, Multi-Family Building Construction, NISTIR 4724, National Institute of Standards and Technology, Gaithersburg, MD (1991).

[52] Cohen JD, and Stratton RD. Home destruction examination - Grass Valley Fire. USDA Forest Service Report R5-TP-026b. 2008.

[53] Cohen JD. An Examination of the Summerhaven, Arizona Home Destruction Related to the Local Wildland Fire Behavior during the June 2003 Aspen Fire, US Department of Agriculture, Forest Service, Rocky Mountain Research Station, Missoula, MT (2003).

[54] Maranghides A and Mell W. A case study of a community affected by the Witch and Guejito fires. NIST Technical Note 1635. April 2009.

[55] Caton SE, Hakes RSP, Gollner MJ, Gorham DJ, and Zhou A. Review of pathways for building fire spread in the wildland urban interface Part I: Exposure conditions. Fire Technology (2017) 53: 429-473. DOI: 10.1007/s10694-016-0589-z.

[56] Hakes RSP, Caton SE, Gollner MJ, Gorham DJ. A review of pathways for building fire spread in the wildland urban interface Part II: Response of components and systems and mitigation strategies in the United States. Fire Technology (2017) 53: 475-515. DOI: $10.1007 / \mathrm{s} 10694-016-0601-7$

[57] Laranjeiraa J, Cruz H. Building vulnerabilities to fires at the wildland urban interface. Chapter 3 in Advances in Forest Fire Research- Fire Management. Editors: Imprensa 
da Universidade de Coimbra. Available at http://dx.doi.org/10.14195/978-989-260884-6_76

[58] Grishin AM, Filkov AI, Loboda EL, Reyno VV, Kozlov AV, Kuznetsov VT, Kasymov DP, Andreyuk SM, Ivanov AI, and Stolyarchuk. A field experiment on grass fire effects on wooden constructions and peat layer ignition. International Journal of Wildland Fire (2014) 23; 445-449. http://dx.doi.org/10.1071/WF12069.

[59] Stephens SL, Molina DM, Carter R, Martin RE. Comparison of Fuel Load, Structural Characteristics, and Infrastructure Before and After the Oakland Hills Tunnel Fire, in Weise, D, R. and Martin, R. E., eds., The Biswell Symposium: Fire Issues and Solutions in Urban Interface and Wildland Ecosystems, General Technical Report PSW-GTR158, US Department of Agriculture, Forest Service, Pacific Southwest Research Station, Albany, CA, 189-191 (2005).

[60] Maranghides A, Mc Namara D, Mell W, Trook J, and Toman B. A case study of a community affected by the Witch and Guejito fires report: \#2-Evaluating the effects of hazard mitigation actions on structure ignitions. NIST Technical Note 1796. May 2013. http://dx.doi.org/10.6028/NIST.TN.1796

[61] Maranghides A and McNamara D. 2011 Wildland urban interface Amarillo fire report \#2- Assessment of fire behavior and WUI measurement science. NIST TN 1909. February 2016. http://dx.doi.org/10.6028/NIST.ITN.1909.

[62] Cohen JD and Butler BW. Modeling potential structure ignitions from flame radiation exposure with implications for wildland/urban interface fire management. 13th Fire and Forest Meteorology Conference. Lorne, Australia 1996.

[63] Maranghides A, Mell W, Ridenour K, McNamara D. Initial Reconnaissance of the 2011 Wildland-Urban Interfaces Fires in Amarillo, Texas. NIST TN 1708.

http://dx.doi.org/10.6028/NIST.TN.1910

[64] Ramsay GC, McArthur NA, and Dowling VP, Preliminary-results from an examination of house survival in the 16 February 1983 bushfires in Australia, Fire and Materials (1987)11: 49-51.

[65] Leonard JE, and McArthur NA, A History of Research into Building Performance in Australian Bushfires, Proceedings of the Australian Bushfire 99 Conference, Albury, NSW, Australia, 219-225 (1999).

[66] Blanchi R. and Leonard J. Investigation of Bushfire Attack Mechanisms Resulting in House Loss in the ACT Bushfire 2003, Bushfire CRC Report CMIT Technical Report - 2005-478 (April 2005).

[67] Viegas DX, Almedia M, Raspo J, Oliveria R, Vigeas CX. Ignition of mediterranean fuel beds by several types of firebrands. Fire Technology (2014) 50: 61-77.

[68] Ganteaume A, Guijarro M, Jappiot M, Hernando C, Lampin-Maillet C, PerezGorostiaga P, and Vega JA. Laboratory characterization of firebrands involved in spot fires. Annals of Forest Science (2011) 68: 531-541. 
[69] Manzello SL, Maranghides A, Mell WE. Firebrand generation from burning vegetation. International Journal of Wildland Fire (2007) 16: 458-462. doi:10.1071/WF06079

[70] Manzello SL and Foote EID. Characterizing firebrand exposure from wildlandurbaninterface (WUI) fires: results from the 2007 Angora fire. Fire Technology (2014) 50: $105-124$.

[71] Pellegrino JL, Bryner NP, Johnsson EL. Wildland-urban interface fire research needs workshop summary report. NIST (2013).

[72] Warey A. Influence of thermal contact on heat transfer from glowing firebrands. Case Studies in Thermal Engineering (2018) 12; 301-311.

[73] Ganteaume A, Maillet CL, Guijarro M, Hernando C, Jappiot M, Fonturbel T, RerezGorostiaga P, and Vega JA. Spot fires: fuel bed flammability and capability of firebrands to ignite fuel beds. International Journal of Wildland Fire (2009)18: 951969.

[74] Ellis PFM. The Likelihood of ignition of dry-eucalypt forest litter by firebrands. International Journal of Wildfire (2015) 24: 225-235.

[75] Urban JL, Zak CD, and Fernandez Pello C. Spot fire ignition of natural fuels by hot aluminum particles. Fire Technology (2018) 54; 797-808.

[76] Moghtaderi B, Poepowati T, Kennedy EM, and Dlugogorski BZ. The role of extinction on the re-ignition potential of wood-based embers in bushfires. International Journal of Wildland Fire (2007)16: 547-555.

[77] Matvienko OV, Kasymov DP, Filkov AI, Daneyko OI, and Gorbatov DA. Simulation of fuel bed ignition by wildland firebrands. International Journal of Wildland Fire (2018) 27: 550-561.

[78] Hedayati F, Bahrani B, Zhou A, Quarles SL and Gorham DJ. A framework to facilitate firebrand characterization. Frontiers in Mechanical Engineering (2019) 5: 43 doi: 10.3389/fmech.2019.00043.

[79] Blunck DL, Butler B, Bailey J, and Wagenbrenner N. Multi-Scale Study of Ember Production and Transport under Multiple Environmental and Fuel Conditions. Final Report FSP PROJECT ID:15-1-04-9, October 2019.

[80] Suzuki S, Brown A, Manzello SL, Suzuki J, and Hayashi Y. Firebrands generated from a full-scale structure burning under well-controlled laboratory conditions. Fire Safety Journal (2014) 63: 43-51.

[81] Suzuki S and Manzello S. Firebrand production from building components fitted with siding treatments. Fire Safety Journal (2016) 80: 64-70.

[82] Suzuki S and Manzello S. Investigating effect of wind speeds on structural fire brand generation in laboratory scale experiments. International Journal of Heat and Mass Transfer (2019) 130: 135-140. 
[83] Woycheese JP, Wooden combustion for spot fire spread. In proceedings of the $9^{\text {th }}$ International Interflam Conference Edingburgh, September 17-19 2001, Interscience Communication Ltd., England, pp 101-112.

[84] Bouvet N, Link ED, and Fink SA. Development of a new approach to characterize firebrand showers during wildland-urban interface (WUI) fires: a step towards highfidelity measurements in three dimensions. NIST TN 2093, Available at: https://doi.org/10.6028/NIST.TN.2093.

[85] Fateev V, Agafontsev M, Volkow S, and Filkov A. Determination of smoldering time and thermal characteristics of firebrands under laboratory conditions. Fire Safety Journal. (2017) 9: 791-799.

[86] Manzello SL and Suzuki S. Experimental investigation of wood decking assemblies exposed to firebrand showers. Fire Safety Journal (2017) 92: 122-131. https://doi.org/10.1016/j.firesaf.2017.05.019.

[87] Abul-huda YM. Development of a spatially resolved optical technique for measuring heat flux and thermal footprint of firebrand piles. NIST Technical. Note 205228 (2019).

[88] Ohlemiller TJ. Smoldering Combustion, National Bureau of Standards, NBSIR 853294 (1986)

[89] Hadden R, Alkatib A, Rein G, Torero JL. Radiant ignition of polyurethane foam: the effect of sample size. Fire Technology (2014)50: 673-691.

[90] Rein G. Smoldering Combustion, SFPE Handbook $5^{\text {th }}$ Edition, Hurley, M.J. ed., pp. 581-603 (2016).

[91] Ohlemiller, TJ. Modeling of smoldering combustion propagation. Progress in Energy and Combustion Science (1985)11: 277-310.

[92] White RH and Dietenberger MA. Wood Products: Thermal Degradation and Fire. In Encyclopedia of Materials: Science and Technology, pp 9712-9716.

[93] Rein G, Carlos Fernandez-Pello A, and Urban DL. Computational model of forward and opposed smoldering combustion in microgravity. Proc. Combust. Inst. 31, 26772684(2007). doi: 10.1016/j.proci.2006.08.047

[94] Dodd AB, Lautenberger C, Fernandez-Pello C. Computational modeling of smolder combustion and spontaneous transition to flaming. Combustion and Flame (2012) 159: 448-461.

[95] Saidi MS, Hajaligol MR, Mhaisekar A, and Subbiah M. A 3D modeling of static and forward smoldering combustion in a packed bed of materials. Applied Mathematical Modelling (2007), 31: pp. 1970-1996

[96] Yang J, Rein G., Chen H. Smoldering Propensity in Upholstered Furniture: Using Computational and Experimental Methods to Aid the Selection of an Appropriate $\begin{array}{llllll}\text { Smoldering Scenario. NIST Technical Note } 2087 & \text { (2020) }\end{array}$ https://doi.org/10.6028/NIST.TN.2087 
[97] Ohlemiller T. Smoldering combustion propagation on solid wood. In: G. Cox (Ed.) Fire Safety Science-Proceedings of the Third International Symposium, (1991), IAFSS, 3:565, http://dx.doi.org/10.3801/IAFSS.FSS.3-565.Dowling VP. Ignition of timber bridges in bushfires, Fire Safety Journal (1994) 22: 145-168.

[99] Manzello SL, Suzuki S, and Hayashi Y. Exposing siding treatments, walls fitted with eaves, and glazing assemblies to firebrand showers. Fire Safety Journal (2012) 50: 2534.

[100] Hagen BC. Onset of smoldering and transition to flaming fire. Doctoral Thesis submitted to Department of Physics and Technology University of Bergen, April 2013.

[101] Putzeys O, Bar-Ilan Aa, Rein G, Fernandez-Pello AC, and Urban DL. The role of secondary oxidation in the transition of smoldering to flaming. Proceedings of the Combustion Institute 31 (2007) 2669-2676.

[102] Mikalsen RF. Fighting flameless fires: Initiating and extinguishing self-sustained smoldering fires in wood pellets. Doctoral Thesis submitted to the Faculty of Process and Systems Engineering of the Otto-von-Guericke-University of Magdeburg, 2018.

[103] Hadden RM, Scott S, and Fernandez-Pello AC. Ignition of combustible fuel beds by hot particles: An experimental and theoretical study. Fire Technology (2011) 47: 341355.

[104] Ronda A, Zassa MD, Biasin A, Martin-Lara MA, and Canu P. Experimental investigation on the smoldering of pine bark. Fuel (2017) 193: 81-94.

[105] Wessies SS, Chang MK, Marr KC and Ezekoye OA. Experimental and analytical characterization of firebrand Ignition of home insulation materials. Fire Technology (2019) 55: 1027-1056. https://doi.org/10.1007/s10694-019-00818-8

[106] Torero JL. Flaming ignition of solid fuels. In: Dinenno PJ, Drysdale D, Beyler CL, Walton WD, Custer RLp (eds) SFPE handbook of fire protection engineering, Published by the National Fire Protection Association, National Fire Protection Association, Inc., One Batterymarch Park Quincy, Massachusetts (2008).

[107] Kasymov DP, Agafontsev MV, Perminov VV, Tarakanova VA. Studying the resistance to fire of wood under the different type of thermal impact while forest fires. Proc. SPIE 10833, 24 ${ }^{\text {th }}$ International Symposium on Atmospheric and Ocean Optics: Atmospheric Physics, 1083356 (13 December 2018); doi:10.1117/12.2504454

[108] Beyler C, Dinaburg J, and Mealy C. Development of test methods for assessing the fire hazard of landscaping mulch. Fire Technology (2014) 50: 39-60.

[109] McArthur NA and Lutton P. Ignition of exterior building details in bushfires: An experimental study. Fire and Materials (1991) 15: 59-64.

[110] Friquin KL. Material properties and external factors influencing the charring rate of solid wood and glue-laminated timber. Fire and Materials (2011) 35(5): 303-327.

[111] Yin P, Liu N, Chan H, Lozano JS, and Shan Y. New correlation between ignition time and moisture content for pine needles attacked by firebrands. Fire Technology (2014) 50: 79-91. DOI: 10.1007/s10694-012-0272-y 
[112] Grishin AM, Dolgov AA, Zima VP, KryuchovDA, Reino VV, Subbotin AN, and Tsvyk RSh. Ignition of a layer of combustible forest materials. Combustion, Explosion, and Shock Waves (1998) 34(6): 613-620.

[113] Davies GM and CJ Legg. Fuel moisture thresholds in the flammability of Calluna Vulgaris. Fire Technology (2011) 47: 421-436. DOI: 10.1007/s10694-010-0162-0.

[114] Bartlett AI, Hadden RM, and Bisby LA. A review of factors affecting the burning behavior of wood for application to tall timber construction. Fire Technology (2019) 55: 1-49. //doi.org/10.1007/s10694-018-0787-y

[115] Wang S, Huang X, Chen H, and Liu N. Interaction between flaming and smouldering in hot- particle ignition of forest fuels and effects of moisture and wind. International Journal of Wildland Fire (2017) 26: 71-81.

[116] Fernandez-Pello AC. Wildland fire spot ignition by sparks and firebrands. Fire Safety Journal (2017) 91: 2-10.

[117] Ellis PFR. Fuelbed ignition potential and bark morphology explain the notoriety of the eucalypt messmate 'stringybark' for intense spotting. International Journal of Wildland Fire (2011) 20: 897-907.

[118] Krause U and Schmidt M. The influence of initial conditions on the propagation of smouldering fires in dust accumulations. Journal of Loss Prevention in the Process Industries (2001) 14: 527-532.

[119] Chen X, Zhou Z, Li P, Zhou D and Wang J. Effects of sample orientation on pyrolysis and piloted ignition of wood. Journal of Fire Sciences (2014) 32(6): 483-497.

[120] Yang L, Wang Y, Zhou X, Dai J and Deng Z. Experimental and numerical study of the effect of sample orientation on the pyrolysis and ignition of wood slabs exposed to radiation. Journal of Fire Sciences (2012) 30(3): 211-223.

[121] Babrauskas V. Charring rate of wood as a tool for fire. Investigations. Fire Safety Journal (2005) 40: 528-554.

[122] Suzuki S, Nii D, and Manzello SL. The performance of wood and tile roofing assemblies exposed to continuous firebrand assault. Fire and Materials (2017) 41: 8496.

[123] Manzello SL, Park SH, Suzuki S, Shields JR, and Hayashi Y. Experimental investigation of structure vulnerabilities to firebrand showers. Fire Safety Journal (2011) 46: 568-578.

[124] Kasymov D and Agafontsev M. Studying the effect of fire-retardant coating on the fire hazard characteristics of wood using infrared thermography. EPJ Web of Conferences (2017) 159: 00018. https://doi.org/10.1051/epjconf/201715900018

[125] Suleiman BM, Larfeldt J, Leckner B, Gustavsson M. Thermal conductivity and diffusivity of wood. Wood Science and Technology (1999)33: 465-473.

[126] Rein G. Smoldering Combustion. Chapter 19 in M.J.Hurley et al ( Ed.) SFPE Handbook of Fire Protection Engineering, 5th Edition, Vol 1, Springer, New York (2016) pp. 581-603. 
[127] Vermesi I, DiDomizio MJ, Ritcher F, Weckman EJ, and Rein G. Pyrolysis and spontaneous ignition of wood under transient irradiation: Experiments and a-priori predictions. Fire Safety Journal (2017) 91: 218-225.

[128] Melinek SJ. Ignition behavior of heated wood surfaces. Fire Research Note. No 755. March 1969. Fire Research Station Borehamwood, Herts, UK.

[129] Ohlemiller TJ. Cellulosic insulation material III. Effects of heat flow geometry on smolder initiation. Combustion science and Technology (1981) 26(3-4): 89-105.

[130] Quarles SL and Standohar-Alpano. Ignition potential of decks subjected to an ember exposure. Insurance Institute for Business \& home Safety. October 2017.

[131] Hedayati F, Stansell C, Gorham D, and Quarles SL. Near Building Noncombustible Zone, Wildfire Research. December 2018. Technical Report, Insurance Institute for Business and Home Safety. https://21ro1f2g715d2qfj633cf0mm-wpengine.netdnassl.com/wp-content/uploads/wpmembers/files/Near-

Building_Noncombustible_Zone_Report_IBHS.pdf

[132] Quarles SL. Vulnerability of vents to wind-blown embers. August 2017. https://21ro1f2g715d2qfj633cf0mm-wpengine.netdna-ssl.com/wpcontent/uploads/wpmembers/files/Vulnerability-of-Vents-to-Wind-BlownEmbers_IBHS.pdf

[133] Quarles SL and Sindler M. Wildfire Ignition Resistant Home Design (WIRHD) Program: Full-scale testing and demonstration final report, DE- AI09-00SR22188, December 2011.

[134] Suzuki S and Manzello SL. Experiments to provide the scientific basis for laboratory standard test methods for firebrand exposure. Fire and Safety Journal (2017) 91: 784790.

[135] Suzuki S and Manzello SL. Initial study on thatched roofing assembly ignition vulnerabilities to firebrand showers. Fire Safety Journal (2019) 103; 34-37.

[136] Manzello SL, Suzuki S, and Hayashi Y. Enabling the study of structure vulnerabilities to ignition from wind driven firebrand showers: A summary of experimental results. Fire Safety Journal. (2012) 54:181-196. https://doi.org/10.1016/j.firesaf.2012.06.012

[137] Kaye N and Nguyen D. Improving Disaster Resilience by Quantifying WUI Community Ember Exposure. Presented at the 2020 NIST Disaster Resilience Symposium, July 28 - July 29, 2020.

[138] AS 3959- Australian Standard for Construction of Buildings in Bushfire-Prone Areas.

[139] NFPA 1144 - Standard for Reducing Structure Ignition Hazards from Wildland Fire. Current Edition: 2018.

[140] AS-NZ 1530.8.2: Australian Standard-Methods for fire tests on building materials, components and structures Part 8.2: Tests on elements of construction for buildings exposed to simulated bushfire attack — Large flaming sources

[141] ASTM E136- Standard Test Method for Assessing Combustibility of Materials Using a Vertical Tube Furnace at $750^{\circ} \mathrm{C}$. 
[142] ASTM E84- Standard Test Method for Surface Burning Characteristics of Building Materials.

[143] NFPA 285- Standard Fire Test Method for Evaluation of Fire Propagation Characteristics of Exterior Wall Assemblies Containing Combustible Components

[144] ASTM E119- Standard Test Methods for Fire Tests of Building Construction and Materials.

[145] ASTM E 2707- Standard Test Method for Determining Fire Penetration of Exterior Wall Assemblies Using a Direct Flame Impingement Exposure.

[146] ASTM E 2957- Standard Test Method for Resistance to Wildfire Penetration of Eaves, Soffits and Other Projections

[147] https://www.fema.gov/media-library-data/20130726-172850451351/home_builders_guide_to_construction_in_wildfire_zones.pdf

[148] https://ucanr.edu/sites/fire/Prepare/Building/Windows/

[149] ASTM E 2886- Standard Test Method for Evaluating the Ability of Exterior Vents to Resist the Entry of Embers and Direct Flame Impingement

[150] ASTM E2912- Standard Test Method for Fire Test of Non-Mechanical Fire Dampers Used in Vented Construction.

[151] ASTM E 2257- Standard Test Method for Room Fire Test of Wall and Ceiling Materials and Assemblies

[152] Fabian TZ. Fire performance properties of solid wood and lignocellulose-plastic composite deck boards. Fire Technology (2014) 50, 125-141. DOI: 10.1007/s10694012-0307-4

[153] ASTM E 108- Standard Test Methods for Fire Tests of Roof Coverings.

[154] Pitts WM. Ignition of cellulosic fuels by heated and radiative surfaces. NIST Technical Note 1481, March 2007.

[155] Bean D and Blunck DL. Identifying processes controlling ignition of fuel beds by Firebrands. $11^{\text {th }}$ U.S. National Combustion Meeting Organized by the Western States Section of the Combustion Institute March 24-27, 2019, Pasadena, California

[156] Fernandez-Pello AC, Lautenberger C, Rich D, Zak C, Urban J., Hadden R, Scott S, and Fereres S. Spot fire ignition of natural fuel beds by hot metal particles, embers, and Sparks. Combustion Science and Technology (2015) 187: 269-295. 